The University of Maine

\title{
DigitalCommons@UMaine
}

Marine Sciences Faculty Scholarship

School of Marine Sciences

$5-1-2000$

\section{A Model Study of the Seasonal Circulation in the Gulf of Maine}

\author{
Huijie Xue \\ University of Maine - Main, hxue@maine.edu \\ Fei Chai \\ University of Maine - Main, fchai@maine.edu \\ Neal Pettigrew \\ University of Maine - Main, nealp@maine.edu
}

Follow this and additional works at: https://digitalcommons.library.umaine.edu/sms_facpub

\section{Repository Citation}

Xue, Huijie; Chai, Fei; and Pettigrew, Neal, "A Model Study of the Seasonal Circulation in the Gulf of Maine" (2000). Marine Sciences Faculty Scholarship. 6.

https://digitalcommons.library.umaine.edu/sms_facpub/6 


\title{
A Model Study of the Seasonal Circulation in the Gulf of Maine
}

\author{
Huijie Xue, Fei Chai, and Neal R. Pettigrew \\ School of Marine Sciences, University of Maine, Orono, Maine
}

(Manuscript received 28 May 1998, in final form 24 June 1999)

\begin{abstract}
The Princeton Ocean Model is used to study the circulation in the Gulf of Maine and its seasonal transition in response to wind, surface heat flux, river discharge, and the $M_{2}$ tide. The model has an orthogonal-curvature linear grid in the horizontal with variable spacing from $3 \mathrm{~km}$ nearshore to $7 \mathrm{~km}$ offshore and 19 levels in the vertical. It is initialized and forced at the open boundary with model results from the East Coast Forecast System. The first experiment is forced by monthly climatological wind and heat flux from the Comprehensive Ocean Atmosphere Data Set; discharges from the Saint John, Penobscot, Kennebec, and Merrimack Rivers are added in the second experiment; the semidiurnal lunar tide $\left(M_{2}\right)$ is included as part of the open boundary forcing in the third experiment.

It is found that the surface heat flux plays an important role in regulating the annual cycle of the circulation in the Gulf of Maine. The spinup of the cyclonic circulation between April and June is likely caused by the differential heating between the interior gulf and the exterior shelf/slope region. From June to December, the cyclonic circulation continues to strengthen, but gradually shrinks in size. When winter cooling erodes the stratification, the cyclonic circulation penetrates deeper into the water column. The circulation quickly spins down from December to February as most of the energy is consumed by bottom friction. While inclusion of river discharge changes details of the circulation pattern, the annual evolution of the circulation is largely unaffected. On the other hand, inclusion of the tide results in not only the anticyclonic circulation on Georges Bank but also modifications to the seasonal circulation.
\end{abstract}

\section{Introduction}

The Gulf of Maine summer circulation pattern of Bigelow (1927) delineated a cyclonic circulation in the interior Gulf of Maine (Maine Eddy) and an anticyclonic circulation on Georges Bank (Georges Eddy). Like most shallow seas, circulation in the gulf is likely distorted by the rugged bottom. Inside the gulf there are three principal basins (see Fig. 1), namely the Jordan Basin and the Georges Basin in the eastern gulf and the Wilkinson Basin in the western gulf. These three basins are separated at the 200-m depth. The Brooks (1985) schematic diagram of the vernal circulation in the Gulf of Maine, inferred from the June 1983 hydrography surveys, delineated counterclockwise gyres around Jordan and Wilkinson Basins and an open cyclonic circulating cell in Georges Basin that connected to the New England shelf flow through the Northeast Channel. A circulation schematic (Fig. 2) based on satellite-tracked drifter and hydrographic observations in 1994 (Pettigrew and Hetland 1995; Pettigrew et al. 1997) showed two distinct gyres centered over the two basins in the eastern Gulf

Corresponding author address: Dr. Huijie Xue, School of Marine Sciences, University of Maine, Orono, ME 04469-5741.

E-mail: hxue@maine.edu of Maine and a large, closed cyclonic flow that traced the perimeter of the gyre pair. Data coverage in the western gulf was insufficient to characterize interior flow in that region. A two-month-averaged streamfunction from the model study of Lynch et al. (1996) reproduced the pair of gyres in the eastern gulf, although their positions were somewhat to the south.

Day (1958), based on the analysis of bottle data collected between 1931 and 1956, concluded that in February and March, the Maine eddy was ill-defined and the Georges eddy was not apparent, and that these two counter-rotating eddies were taking form by late April. Bumpus and Lauzier (1965) also found a seasonal variation in the gulfwide circulation with it being strongest and most coherent in the summer and lacking a recognizable pattern in the winter. Vermersch et al. (1979), using the moored current, temperature, and pressure data, found that the winter currents in the western Gulf of Maine were generally consistent with the idea of a cyclonic gyre. However, the lack of spatial coherence suggested that the circulation was heavily influenced by the presence of mesoscale structures. Time series of surface geostrophic flow in 1986-87 from a set of transects centered in Jordan Basin (Brown and Irish 1992) clearly showed the presence of a cyclonic gyre in the interior Gulf of Maine between September and December and that the cyclonic circulation was stronger in late 


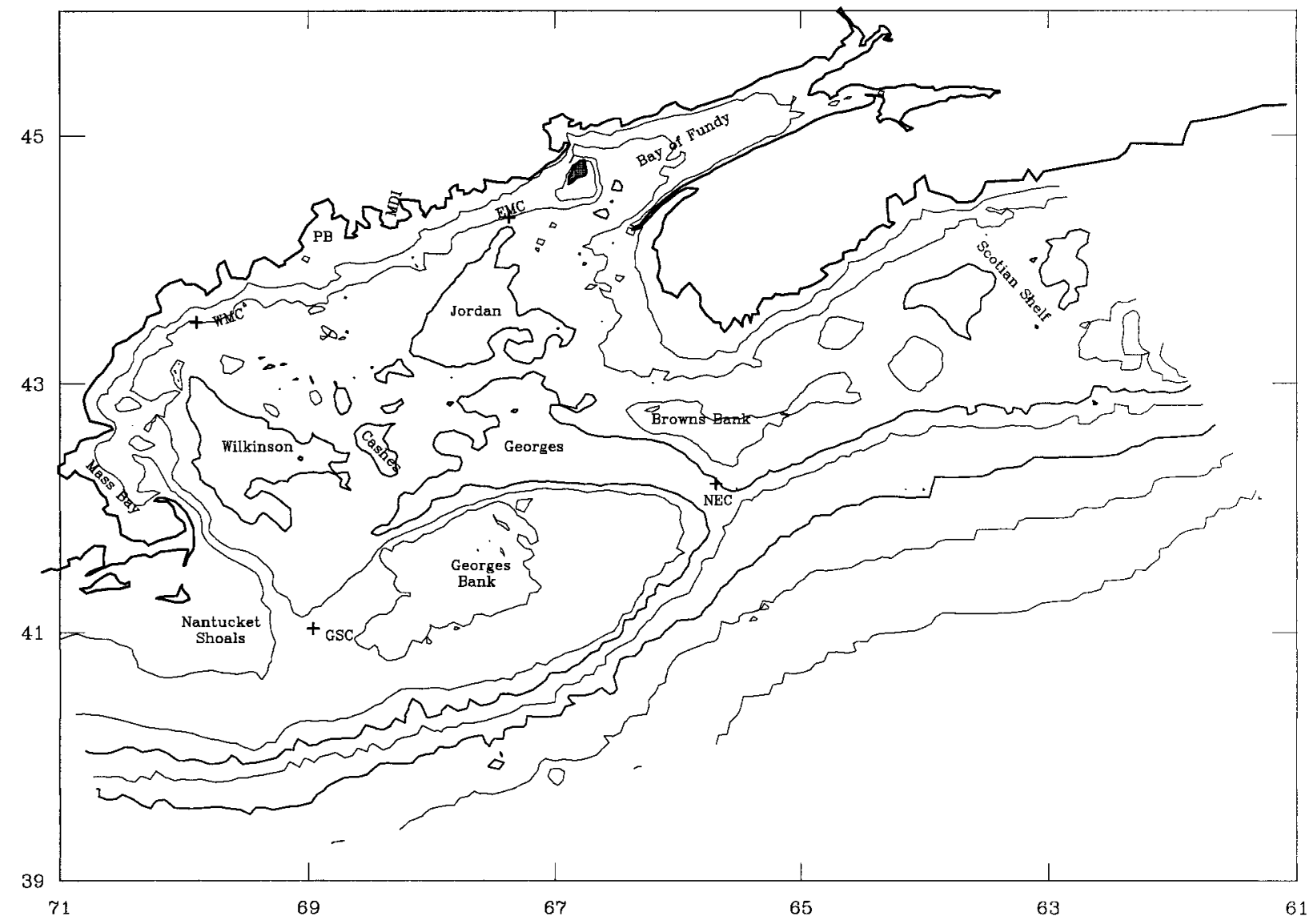

FIG. 1. Map of the Gulf of Maine and its adjacent shelf/slope regions. Heavy contours are the coastline, 200 and 2000-m isobaths. The 200-m isobath separates the three deep basins in the gulf. Thin curves are 50,100, 1000, 3000, and $4000 \mathrm{~m}$ isobaths. At the seaward edge, two subsurface banks $(<100 \mathrm{~m})$ limit the exchange between the gulf and the Atlantic Ocean. Topographic features referred in the text are labeled (in addition to the names already spelled out) are MDI: Mount Desert Island, PB: Penobscot Bay, EMC: eastern Maine coast, WMC: western Maine coast, GSC: Great South Channel, NEC: Northeast Channel. The shaded area at the mouth of the Bay of Fundy is Grand Manan Island; plus signs highlight the locations where time series are taken and shown in Figs. 6, 11, and 15.

fall (November and December). During January, the surface geostrophic flow became increasingly anticyclonic. There was the cyclonic tendency between March and April, but the surface geostrophic flow did not form a cyclonic gyre in the spring of 1987 . The authors concluded that this anomalous pattern was probably due to the excessive runoff that year. Seasonal variations have been noted on Georges Bank with the strongest current on its northern flank during summer (Butman et al. 1987; Naimie et al. 1994).

Although the summer circulation pattern in the gulf is becoming increasingly clear, the circulation in winter, the transitions between seasons, and the factors that regulate the seasonal circulation are less certain. It has been suggested that the circulation in the gulf is related to its evolving density structure (Bigelow 1927; Brooks 1985; Brown and Irish 1992). Brooks and Townsend (1989) and Brooks (1990) speculated that the summertime cyclonic circulation spins up in response to the density contrast between the coastal water and the interior gulf and the stratification in the vertical.
Factors that influence the density distribution inside the gulf include wind, winter cooling, river runoff, the inflow from the Scotian Shelf, the deep inflow of the slope water, and tidal mixing. Wind changes from predominantly northwesterly in winter to predominantly southwesterly in summer, which may provide summer upwelling along the Maine coast. Winter cooling erodes the stratification in the upper water column, whereas the warming in summer reestablishes the stratification. Freshwater discharge along the gulf perimeter peaks during April and May. The freshened bulge near the estuary mouth can induce an upper-level coastal current with the coast to its right (e.g., Chao and Boicourt 1986). The coastal current in the eastern Gulf of Maine, commonly referred to as a tidally mixed plume arising from the discharges of fresh meltwater in spring, flows southwestward along the Maine coast (Brooks 1994; Brooks and Townsend 1989; Lynch et al. 1997; Pettigrew et al. 1998). While Brooks (1994) and Lynch et al. (1997) emphasized the potential effects of the Penobscot plume in steering the coastal current offshore, the study of 


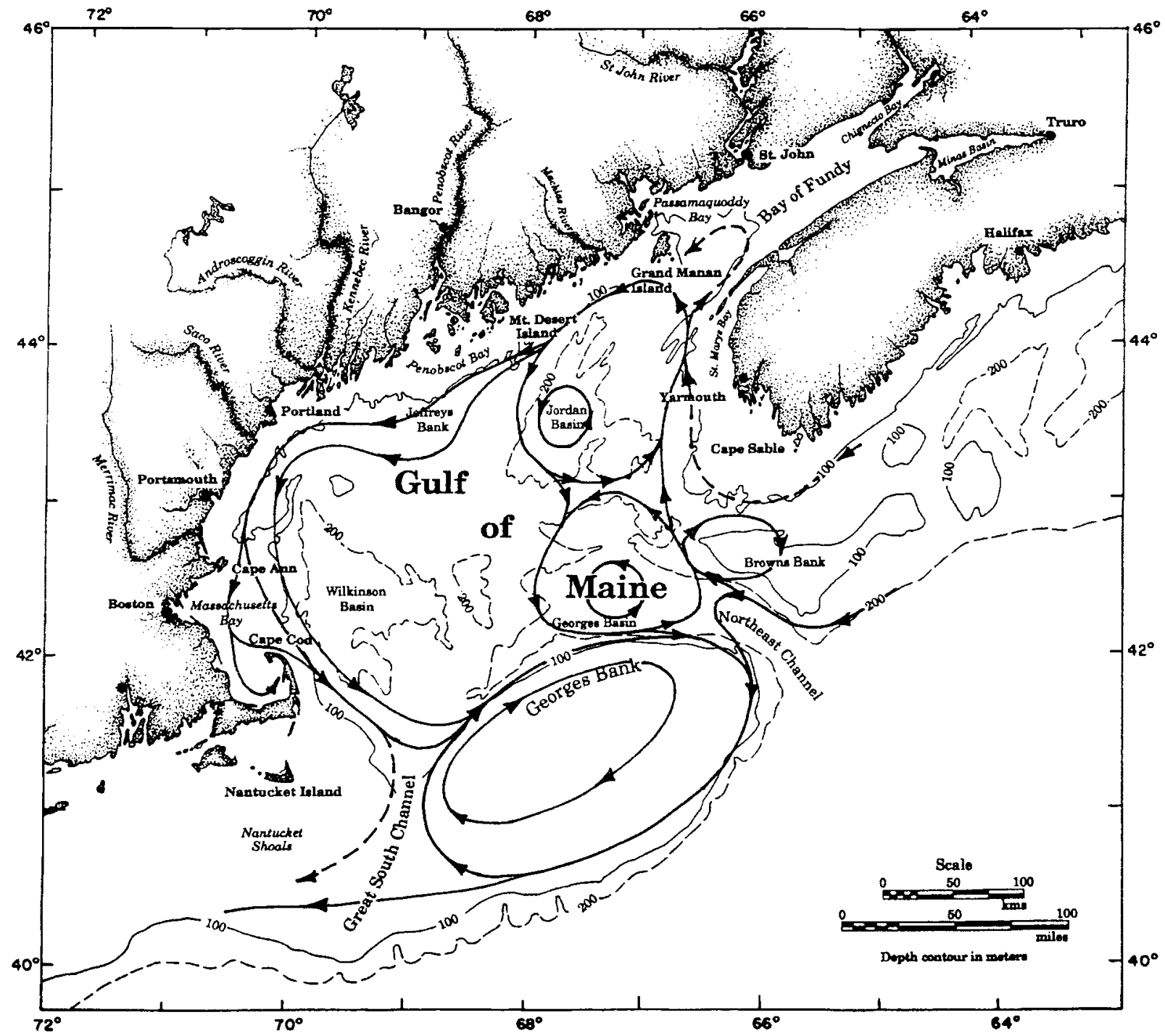

FIG. 2. Schematic of the vernal circulation in the Gulf of Maine. Based on the drifter (drogued at 10 and $40 \mathrm{~m}$ ) and hydrographic observations in the spring of 1994 (N. R. Pettigrew, unpublished manuscript).

Pettigrew et al. (1998) showed evidence of an east Maine coastal current (EMCC) prior to the spring freshet, and examples of offshore excursions well east of Penobscot Bay.

The flow field inside the 100-m isobath is also largely influenced by tides. The Gulf of Maine and Bay of Fundy system is well known for its nearly resonant semidiurnal tidal responses (Garrett 1972; Greenberg 1979). Tidal currents of $1 \mathrm{~m} \mathrm{~s}^{-1}$ or greater are found over the offshore banks and the western Scotian Shelf. Tides dominate flow variability in many locations and also affect longer period variability through nonlinear tidal rectification and tidal mixing (Loder 1980; Loder and Greenberg 1986; Noble et al. 1983; Tee et al. 1993; Chen et al. 1995). Vigorous tidal stirring keeps the water vertically well mixed over Georges Bank, the western shelf of Nova Scotia, in parts of the Bay of Fundy (Loder and Greenberg 1986), and the eastern Maine shelf (Pettigrew et al. 1998). The result is a tidally mixed region separated from the stratified region by a tidal front. On Georges Bank the frontal currents contribute significantly to the vernal anticyclonic flow and the transport of fish larvae (e.g., Townsend and Pettigrew 1996).

The Gulf of Maine is also influenced by dynamic processes upstream over Scotian Shelf and processes offshore in the slope water. It is known that a mixture of St. Lawrence River water and the Labrador Current water enters the Gulf of Maine over the Scotian Shelf (Bumpus 1960; Sutcliffe et al. 1976; Chapman and Beardsley 1989). On the annual average, the alongshore volume transport across the Halifax section was estimated at $0.35 \mathrm{~Sv}\left(\mathrm{~Sv} \equiv 10^{6} \mathrm{~m}^{3} \mathrm{~s}^{-1}\right)$ southwestward with the maximum in January (Drinkwater et al. 1979). Smith (1983) showed that about 0.14 Sv of Scotian Shelf water 
(SSW) flows around Cape Sable and enters the Gulf of Maine. Satellite-derived sea surface temperature shown by Bisagni et al. (1996) and Pettigrew et al. (1998) suggested that the inflowing SSW may have seasonally varying patterns within the gulf. The majority turns southwestward near Grand Manan Island, but part flows cyclonically in the Bay of Fundy in spring and then leaves the bay to feed the EMCC. Furthermore, Pettigrew et al. (1998) found substantial modifications of the thermohaline structure in the eastern Gulf of Maine by the cold and less saline SSW.

Dense slope water enters the Gulf of Maine through Northeast Channel. Ramp et al. (1985) found that the inward transport of the slope water was at its minimum in April and May. It increased rapidly in June and reached a maximum in August, followed by a slight reduction in the fall and a second maximum in the winter. During summer the inflow was steady, whereas during winter it was episodic, but strong, and correlated well with alongshore winds. Inside the gulf the slope water was observed to spread over Lindenkohl sill and move from Georges Basin toward the northwest (Brooks 1990).

The above review reveals an extremely complex Gulf of Maine system in which various processes of different spatial and temporal scales (e.g., river discharges, winds, heat fluxes, inflows, and tides) operate simultaneously. In order to understand how changes in one of the factors above may substantially perturb the annual cycle, it is important to evaluate the role that each of them plays. Early models of the Gulf of Maine were focused on the tide and wind-driven circulation. Greenberg (1979) developed a barotropic model to examine the $M_{2}$ tide and resonance periods of the Gulf of Maine and Bay of Fundy. Using the barotropic model, Greenberg (1983) found that the tidal forcing alone generated the clockwise circulation around Georges Bank and Nantucket Shoals, whereas the interior cyclonic circulation appeared only when the model was forced by steady northeasterly winds. Wright et al. (1986) simulated a steady-state barotropic response of the Gulf of Maine to surface wind stress and sea-level setup on the Scotian Shelf. Diagnostic models of Isaji et al. (1984) and Lynch et al. (1992) computed three-dimensional, wind-driven and tidal circulation in the Gulf of Maine in which the flow fields adjusted to steady density distributions determined from historical temperature and salinity data. Isaji et al. (1984) also studied the effects of the alongshore pressure gradient on the Atlantic continental margin on the Gulf of Maine circulation. Isaji and Spaulding (1984), Wright and Loder (1988), Lynch and Naimie (1993), Naimie et al. (1994), and Chen et al. (1995) examined nonlinear rectification of tidal currents on Georges Bank.

Three-dimensional, prognostic models have also been used in the Gulf of Maine. Brooks (1994) simulated the tidal currents and the influence of river runoff on the coastal current and the interior circulation of the gulf.
His focus was the spring freshet season and the model was integrated for 30 days. Surface forcing was excluded. More recently, Lynch et al. (1996) used a finite element model to simulate circulation in March-April and July-August time periods. The composite circulation shows cyclonic interior flows and anticyclonic flows on Georges Bank. However, they initialized the model in each two-month increment to obtain a composite circulation for those two months, and their model was allowed only nine days for spinup. Given the replacement time of the deep waters in the Gulf of Maine that was estimated at $11 \pm 2$ months by Ramp et al. (1985), numerical models at least need to be integrated that long to reach equilibrium.

We have integrated a three-dimensional, primitive equation, ocean model forward in time for three years to obtain a quasi-equilibrium seasonal circulation for the Gulf of Maine. This paper examines the response of the circulation to wind, surface heat flux, river runoff, and the $M_{2}$ tide, focusing on the seasonal transition of the interior gulf. The following section describes the model and its setup for the Gulf of Maine and the adjoining shelf/slope regions, followed by a discussion on model spinup in section 3. The atmosphere-driven seasonal circulation is illustrated in section 4; effects of wind and surface heat flux are discussed. Section 5 and 6 examine respectively the effects of river discharge and tide on the circulation. Conclusions are given in the final section.

\section{The ocean model}

The Princeton Ocean Model (POM) used in this study has been widely applied to coastal oceans (e.g., Oey et al. 1985a-c; Signell et al. 1994; Skogen et al. 1995). Details on the numerical algorithm of the model are well documented in Blumberg and Mellor (1987) and Mellor (1996). The following is an outline of the main features of the model.

POM is a three-dimensional, fully nonlinear, primitive equation, ocean circulation model. It is forced with surface wind, surface heat and freshwater fluxes, and boundary forcing from open oceans (including tide and inflow), and solves for elevation, three-dimensional velocity, temperature, and salinity. Vertical mixing of subgrid-scale processes is parameterized using the imbedded second-order turbulence closure (Mellor and Yamada 1982). Horizontal mixing coefficients are calculated using the Smagorinsky's (1963) nonlinear formula in which they are related to the scale of motion being resolved in the model and to the local deformation field. POM uses orthogonal curvature, linear coordinates in the horizontal and a sigma coordinate in the vertical, scaled by the height of the water column. A staggered finite difference scheme is used in both the horizontal and the vertical. The implicit scheme used in the vertical eliminates time constraints for the vertical coordinate and permits the use of fine vertical resolution in the 


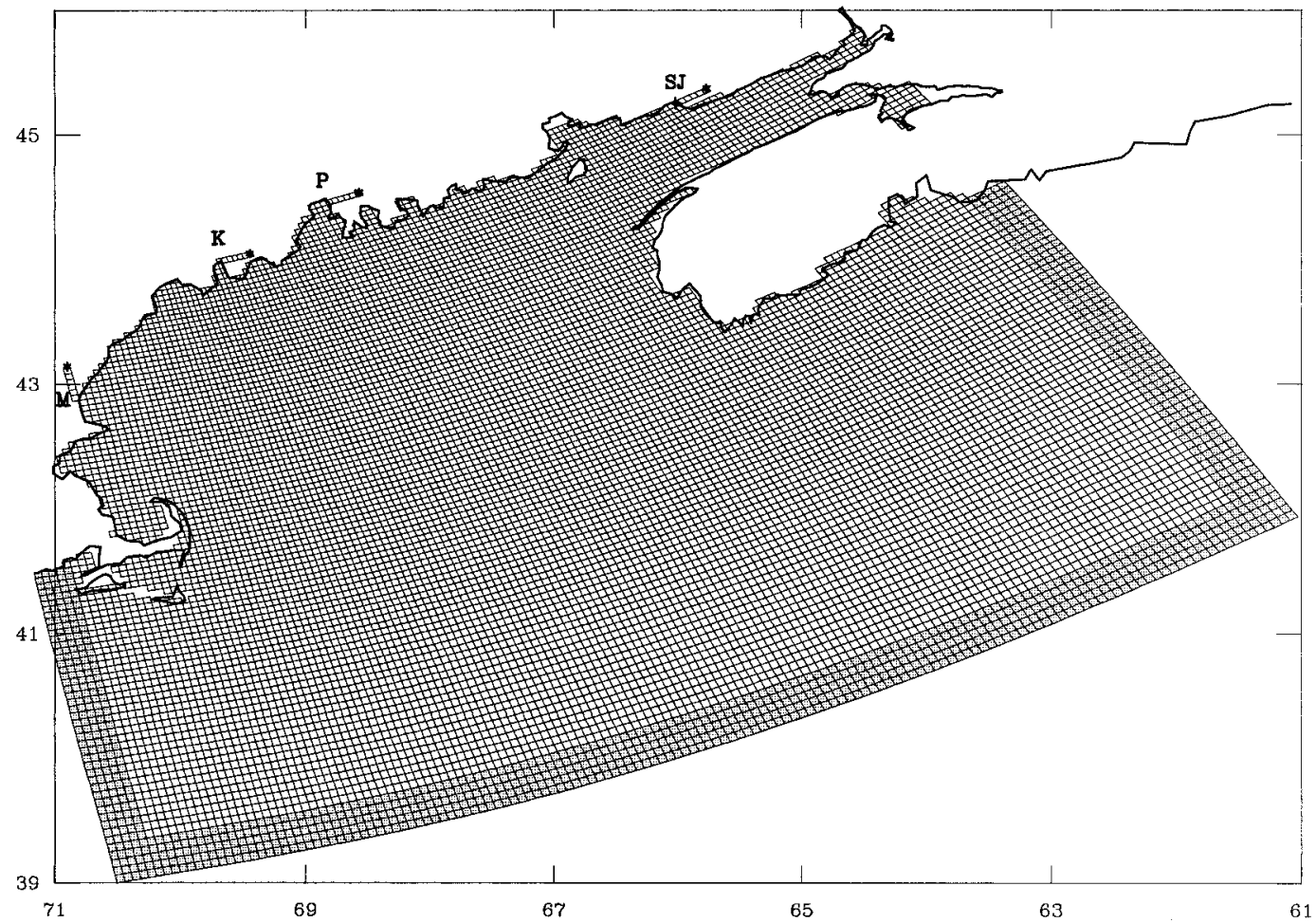

FIG. 3. The orthogonal, curvature linear grid of the model. Shaded area represents a boundary zone in which model variables are relaxed to the prescribed values at the open boundary. Four rivers considered in this study are the Saint John (SJ), Penobscot (P), Kennebec (K), and Merrimack (M) River. Single-sell-width channels have been patched to each of the rivers to allow the development of a two-layer estuarine system. The head of the estuaries is marked by an asterisk $(*)$, and the mouth of the Saint John estuary is marked by a plus sign $(+)$, where velocity and salinity profiles are shown in Fig. 10. Two arrows mark the cross sections referred to in Figs. 19a and 19b.

surface and bottom boundary layers. Although surface elevation is a prognostic variable in the model, POM saves computational time by mode splitting such that the external mode is separated from the internal modes by vertically integrating the governing equations. The external mode provides the surface elevation and vertically integrated velocities to the internal mode, whereas the internal mode provides momentum and density gradient integrals and bottom stress to the external mode.

\section{a. Model configuration and initialization}

The POM was configured in a domain that includes the Gulf of Maine, Georges Bank, the Scotian Shelf, and the adjacent slope region to about 4500-m depth (Fig. 1). The domain was approximately $550 \mathrm{~km}$ in the offshore direction and $800 \mathrm{~km}$ in the alongshore direction. An orthogonal curvature, linear grid was designed to map the domain in 103 by 151 points (Fig. 3) with variable spacing from approximately $3 \mathrm{~km} \times 4 \mathrm{~km}$ near shore to about $6 \mathrm{~km} \times 7 \mathrm{~km}$ offshore. The bottom topography was interpolated from a dataset, provided by David Greenberg at Bedford Institute of Oceanography, that maps the domain to about 1200-m isobath, combining with the ETOPO5 for the rest of the domain in deep waters. There were 19 levels in the vertical with finer resolution near the surface $(\sigma=0.0000,-0.0083$, $-0.0167,-0.0333,-0.0667,-0.1333,-0.2000$, $-0.2667,-0.3333,-0.4000,-0.4667,-0.5333$, $-0.6000,-0.6667,-0.7333,-0.8000 .,-0.8667$, $-0.9333,-1.0000)$. Time steps used in this study were 9 seconds for the external mode and 414 seconds for the internal mode.

A monthly climatology in July from the East Coast Forecast System (ECFS: Aikman et al. 1996) including elevation, three-dimensional velocity, temperature, and salinity was used to initialize all the experiments (Fig. 4). Turbulence quantities were initialized with background values $\left(10^{-8} \mathrm{~m}^{2} \mathrm{~s}^{-2}\right.$ for turbulence kinetic energy, $\left[q^{2}\right]$; and $1 \mathrm{~m}$ for turbulence length scale, $\left.[L]\right)$. The ECFS had a resolution of about $20 \mathrm{~km}$ in the area of this study and was inadequate to simulate many dynamic processes inside the Gulf of Maine, which have Rossby radii on the order of 5 to $10 \mathrm{~km}$. However, the July climatology did show an interior cyclonic circulation, but no anticyclonic circulation on Georges Bank. Salinity inside the gulf was generally too high with the surface salinity greater than 33.5 psu at most locations and the bottom salinity exceeding 35 psu in Jordon and 

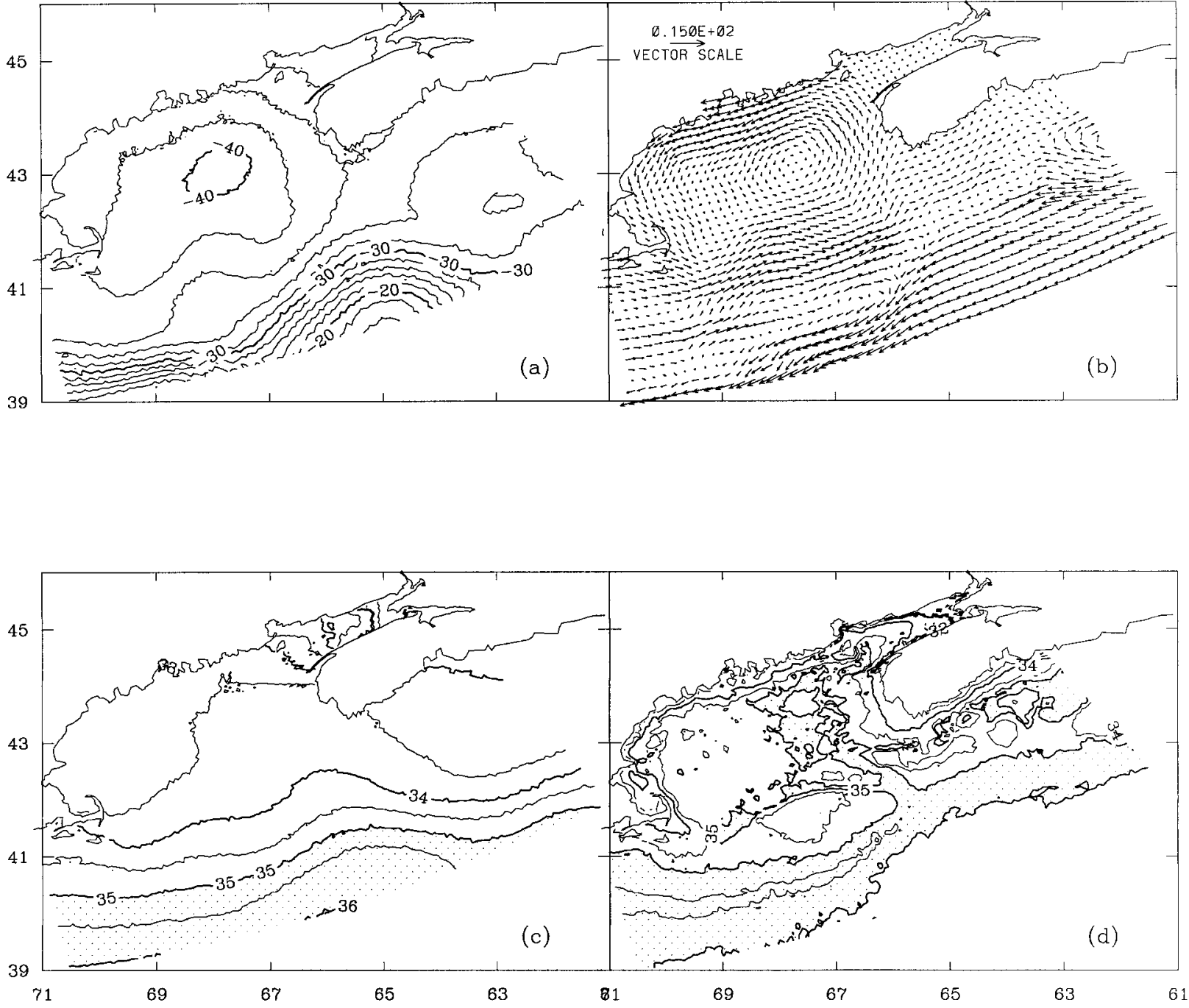

FIG. 4. Monthly mean July condition from the ECFS that is used to initialize the model: (a) surface elevation, (b) vertically averaged velocity, (c) surface salinity, and (d) bottom salinity. Contour intervals are $2 \mathrm{~cm}$ for surface elevation, and 0.5 for salinity.

Georges Basins. The reason for the elevated salinity values might be that the St. Lawrence River discharge was not adequately resolved in the ECFS, resulting in higher salinity on the Scotian Shelf. Observed salinity on the Scotian Shelf ranges from 31 psu near shore to about 32 psu near the shelf break, approximately 2 units lower than the values shown in Fig. 4. Despite the higher salinity at initial time, the influence of initial conditions weakens gradually as time advances and, eventually, effects of the surface and lateral forcing dominate in the model solution.

\section{b. Surface boundary conditions}

Surface forcing [wind, net downward heat flux, and net freshwater flux (evaporation minus precipitation)] was interpolated from the $1^{\circ} \times 1^{\circ}$ monthly climatology of the COADS (Woodruff et al. 1993). Wind and the net downward heat flux in January, April, and July are shown in Fig. 5. Northwesterly winds dominate in winter and southwesterly winds in summer, with transitions occurring in April and September. Monthly averaged winds are strongest in winter, weak during transition periods, and relatively strong again in summer, especially near the coast. During winter, the ocean releases heat to the atmosphere, and the net upward heat flux increases from near shore to the open ocean. Although the air temperature is lower near shore, the air - sea temperature difference is larger over the slope region because the slope water is much warmer. In March and April, the inner gulf begins to receive net downward heat flux. In summer, the net heat flux is from the atmosphere to the ocean, decreasing gradually from the gulf to the slope region. 

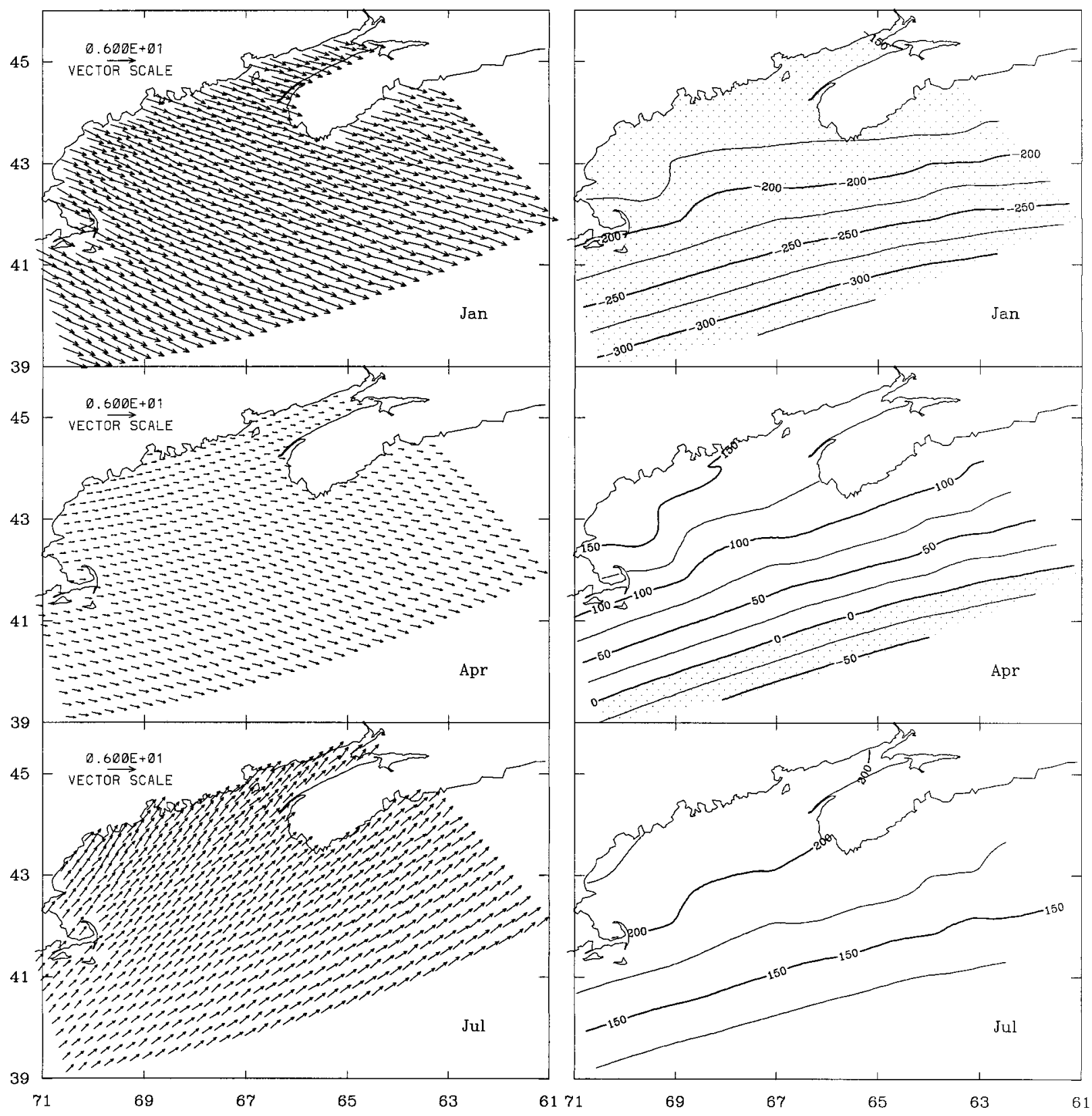

FIG. 5. COADS climatology of monthly mean winds $\left(\mathrm{m} \mathrm{s}^{-1}\right)$ and the net downward heat fluxes $\left(\mathrm{W} \mathrm{m}^{-2}\right)$ in Jan, Apr, and Jul.

\section{c. Lateral boundary condition}

The model domain has three open boundaries: The Scotian Shelf boundary to the northeast represents the most critical upstream (inflow) condition to the simulation (Wright et al. 1986). The southern boundary of the model domain extends into the slope sea where Gulf Stream warm core rings have been observed to encounter Georges Bank and the Northeast Channel and to modify the density structure and flow regime (Brooks 1987; Churchill and Manning 1997). The open boundary to the west links the Gulf of Maine to the Middle
Atlantic Bight. It can influence the circulation in the Gulf of Maine, and the transport across this open boundary needs to be monitored to ensure proper mass balance in the model.

The treatment of open boundary conditions has remained a difficult and important issue in regional numerical models. Various radiation conditions (e.g., Orlanski 1976; Camerlengo and O'Brien 1980; Chapman 1985) have been proposed to allow features generated in the interior domain to pass through the computational boundary, minimizing the contamination of the interior 


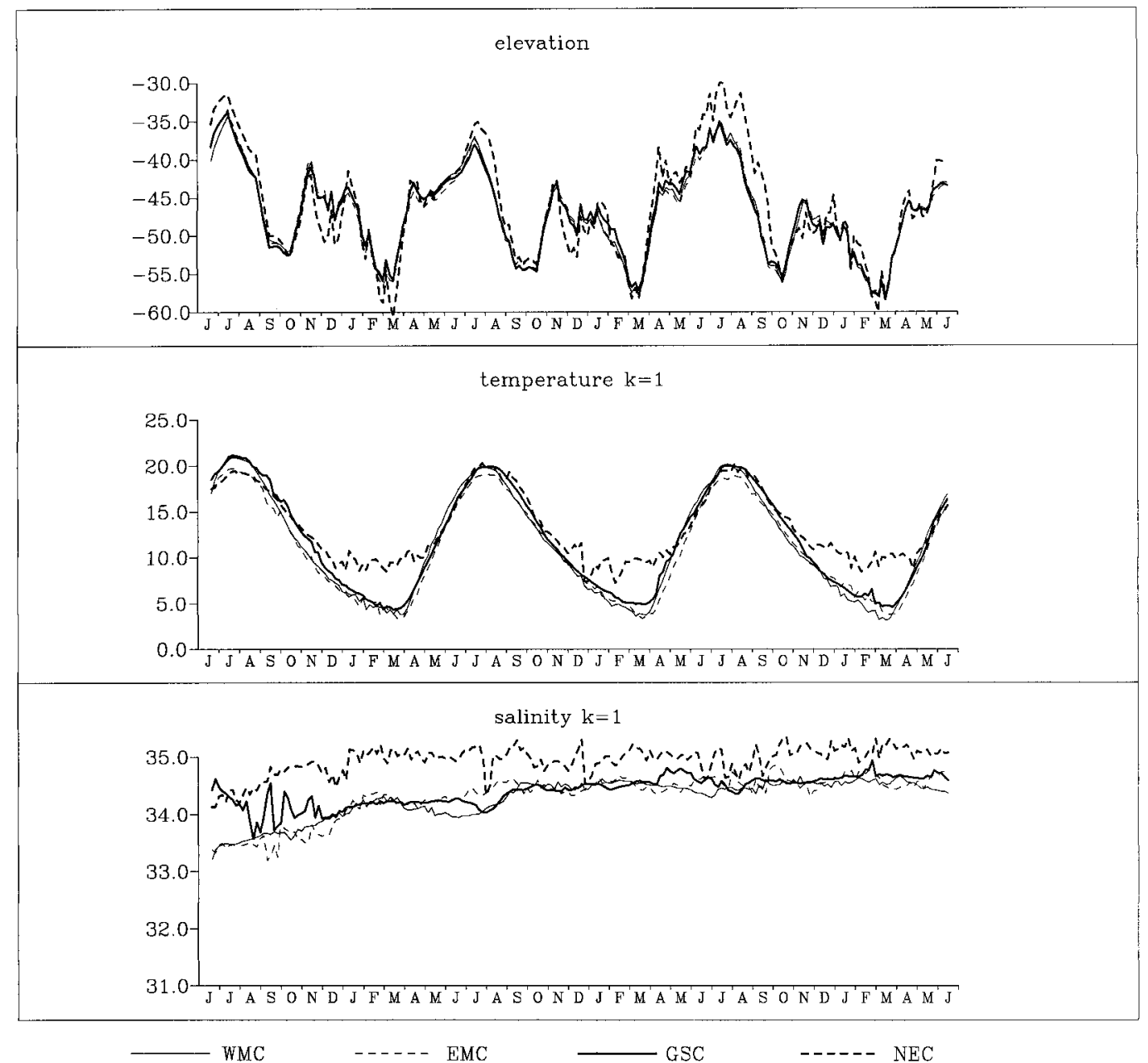

FIG. 6. Time series at four stations indicated by plus signs (+) in Fig. 1, from the experiment forced by monthly climatological wind and heat flux. Top panel shows the surface elevation in $\mathrm{cm}$, middle panel the surface temperature in ${ }^{\circ} \mathrm{C}$, and bottom panel the surface salinity.

solution. On the other hand, nested models in both meteorological and oceanographic applications use the flow field generated by a coarse grid to specify boundary conditions to an embedded fine grid region (Zhang et al. 1986; Spall and Holland 1991). The Gulf of Maine model of this study is embedded in the ECFS such that the ECFS affects the Gulf of Maine region by providing boundary conditions, but there is no mechanism by which the evolution in the Gulf of Maine model can feed back to the ECFS. Such a procedure is called passive nesting and the flow relaxation scheme of Martinsen and Engedhal (1987) has been successfully applied (e.g., Oey and Chen 1992). The following boundary condition combining a radiation condition with a flow relaxation scheme was found to work properly for the present study. A gravity wave radiation condition was applied to the velocity component perpendicular to open boundaries. An upwind-advection scheme was applied to temperature, salinity, and the velocity component parallel to the boundary so that in case of inflow the boundary conditions derived from the ECFS were imported by inward velocities. A boundary zone was set up (see Fig. 3 ) in which a Newtonian damping term relaxed the prognostic variables of the model towards the specified external solutions from the ECFS. A linear distribution of the relaxation parameter was assumed such that the damping timescale within the boundary zone varied from $5 \mathrm{~h}$ at the grid points next to the interior to $1 \mathrm{~h}$ at the grid points along the open boundary. When tidal forcing was added in the third experiment, simple cosine functions with specified frequency, amplitudes, and phases were linearly superimposed on the ECFS-predicted elevation along the open boundary (see section 6 for further discussion).

Rivers were completely shut down in the first experiment, normal and tangential velocities and heat and salinity fluxes were set to zero at the coast. The second and the third experiment considered freshwater dis- 

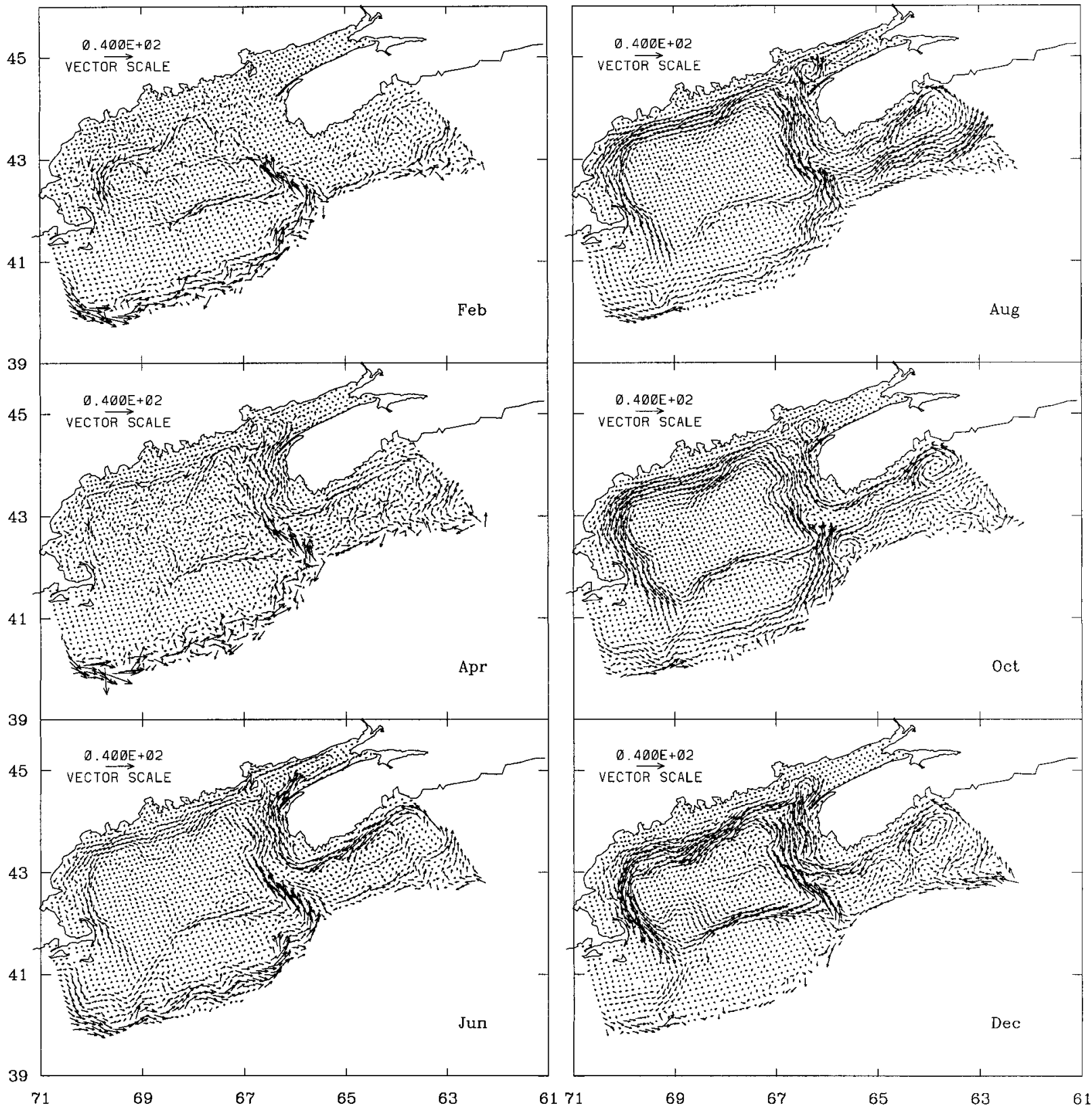

FIG. 7. Monthly averaged velocity $\left(\mathrm{cm} \mathrm{s}^{-1}\right)$ at $10-\mathrm{m}$ depth from the experiment forced by monthly climatological wind and heat flux. Vectors are scaled by $40 \mathrm{~cm} \mathrm{~s}^{-1}$ shown at the upper-left corner of each panel.

charge from the Saint John, Penobscot, Kennebec, and Merrimack Rivers (see section 5 for treatment of rivers in the model).

\section{Model spinup}

The model was run forward in time. The domainintegrated kinetic energy increases by $20 \%$ from the end of the first year to the end of the second year, but it varies by only $2 \%$ from the end of the second year to the end of the third year. The three-year time series of sea surface elevation, temperature, and salinity at four locations $(+\mathrm{s}$ in Fig. 1) from the experiment with atmospheric forcing alone are shown in Fig. 6. Both coastal sites are just outside of the 100-m isobath. The WMC is to the immediate west of the Kennebec River, whereas the EMC is located half way between the Saint John and Penobscot Rivers. NEC and GSC are in the Northeast Channel and Great South Channel, respectively.

An annual cycle has been clearly established in the surface elevation and temperature. Sea surface rises from mid-March until August, then falls more rapidly 

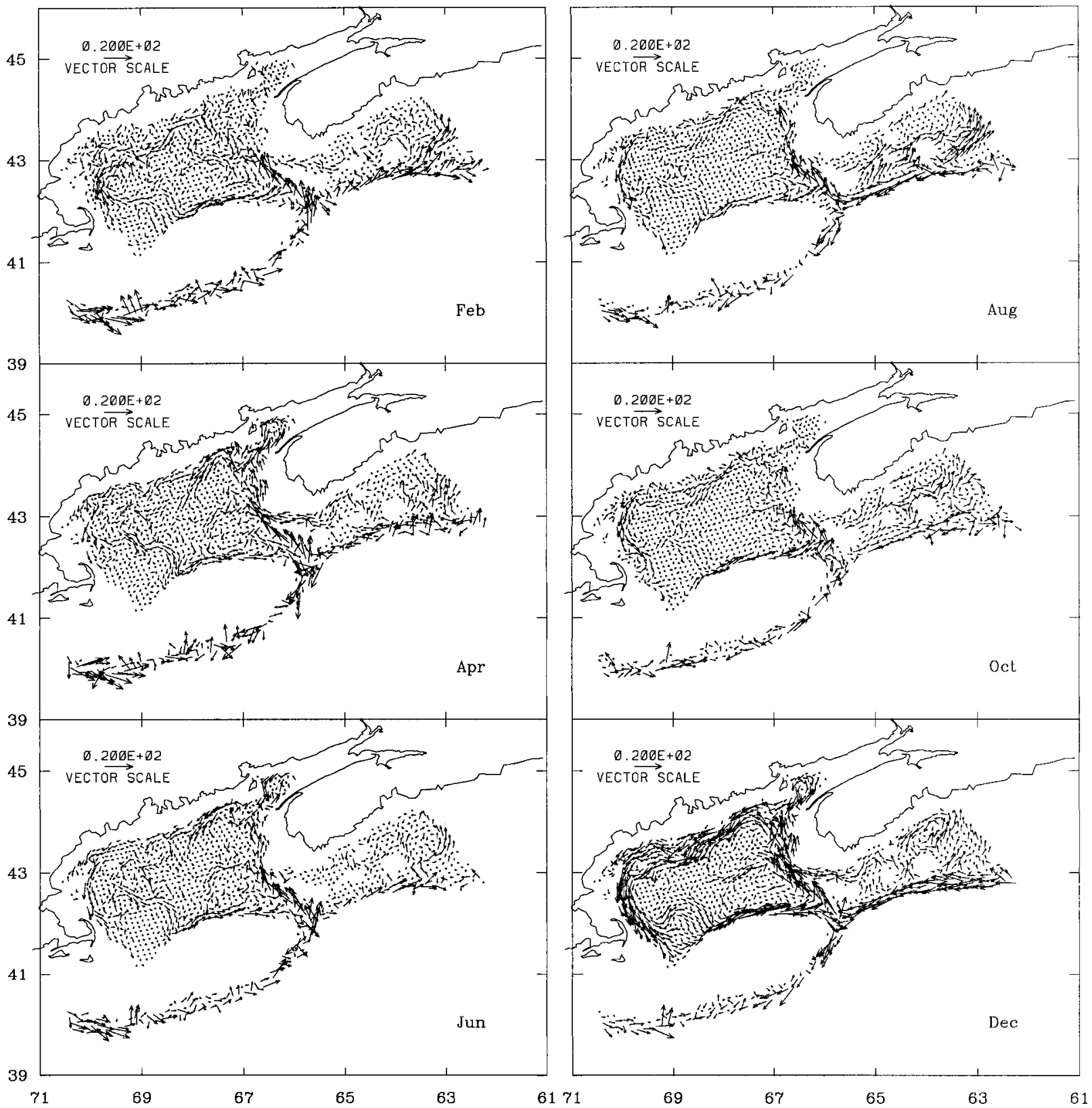

FIG. 8. As in Fig. 7 but at 100-m depth. Vectors are scaled by $20 \mathrm{~cm} \mathrm{~s}^{-1}$ shown at the upper-left corner of each panel.

between August and October, followed by a smaller rise in November that gradually falls back to the minimum in March. Of course, part of this annual cycle comes from the open boundary forcing. It is the difference in sea surface height between the eastern and western gulf and between onshore and offshore that is directly relevant to the interior circulation of interest. SST is primarily controlled by surface heating and cooling. The warming in late spring and early summer tends to be more rapid than the cooling during fall. During winter, the water in Northeast Channel is warmest because of the influence of the slope water. The on/offshore tem- perature difference tends to be greater in winter, especially in the eastern gulf.

Surface salinity in the experiment without river discharge does not show a clear annual cycle. Instead, it has a slower adjustment such that the salinity at all four locations increases during the first model year. Although it is not shown, salinity farther offshore does not increase, suggesting that excessive saline slope water enters the Gulf of Maine in the absence of river inflow. Most importantly, turning off the rivers in the model introduces baroclinic perturbations (i.e., mismatches with the initial salinity field). That the modeled salinity 
(a) steady Jan. Winds

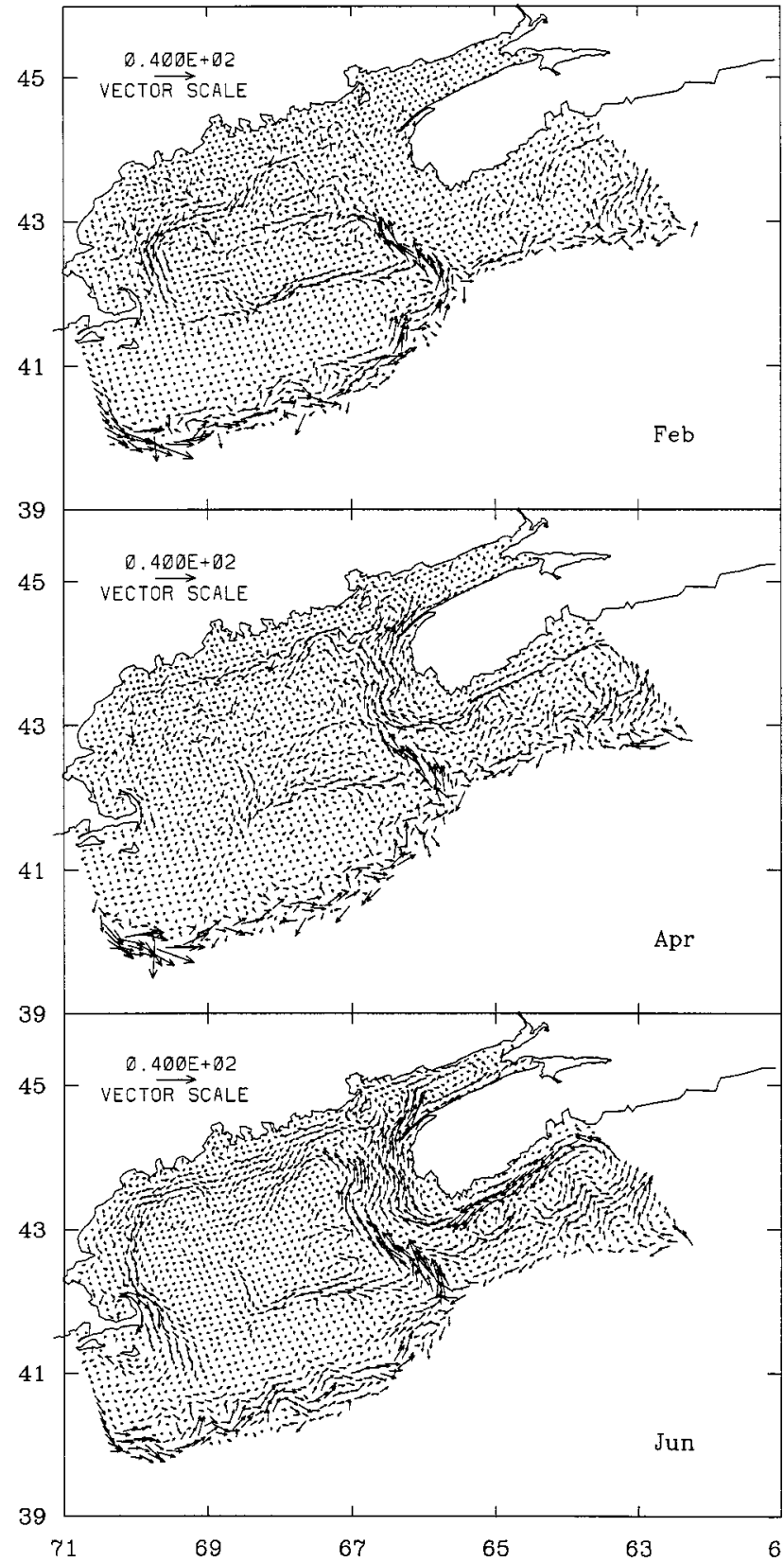

(b) zero heat flux

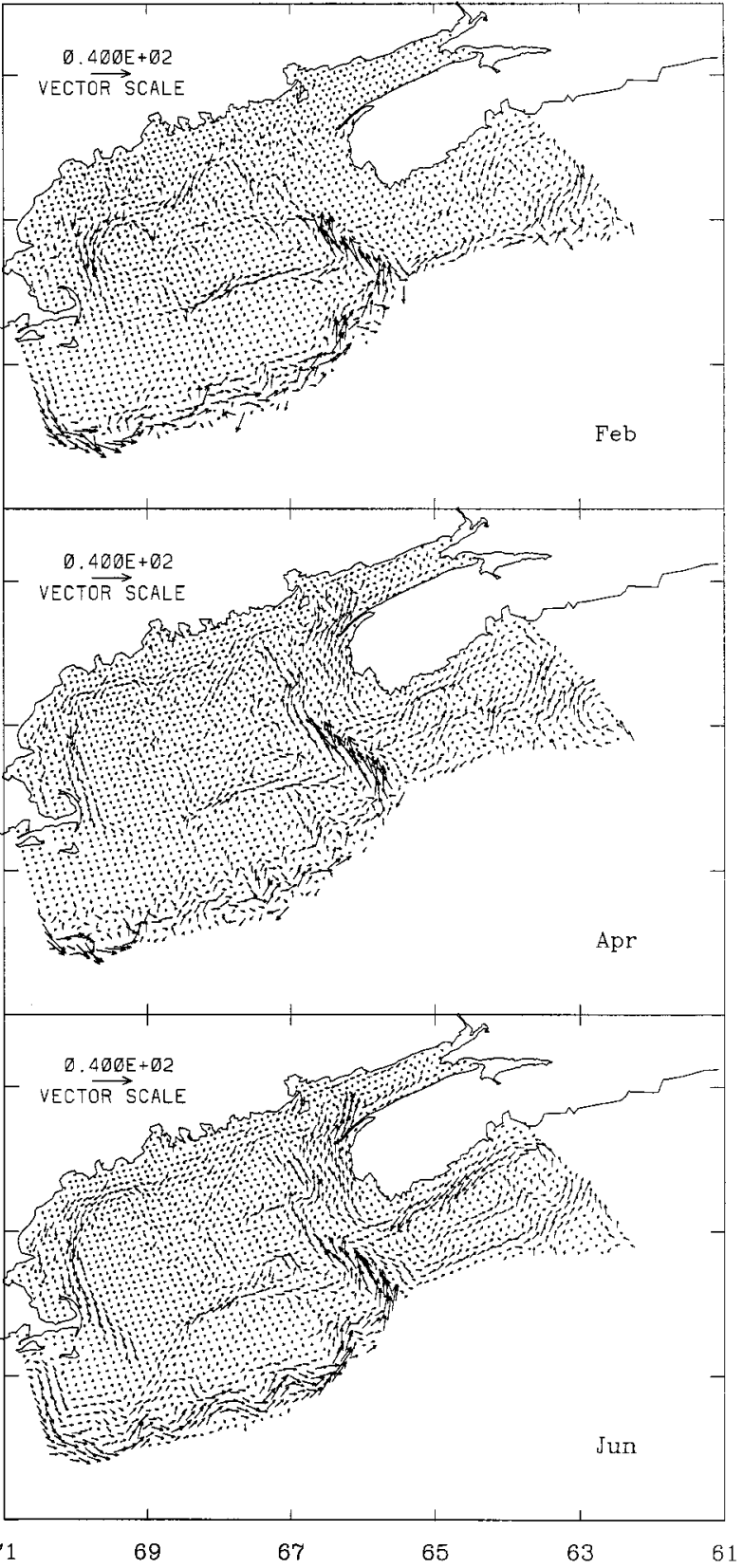

FIG. 9. Monthly averaged velocity $\left(\mathrm{cm} \mathrm{s}^{-1}\right)$ at $10-\mathrm{m}$ depth from the two 6-month integrations for (a) the case forced by monthly heat flux but steady Jan wind and (b) the case forced by monthly wind but zero heat flux. Vectors are scaled by $40 \mathrm{~cm} \mathrm{~s}^{-1}$ shown at the upper-left corner of each panel.

reaches a new equilibrium in year 2 , as seen from rather small changes in salinity from year 2 to year 3 , indicates a baroclinic adjustment time scale in the gulf on the order of one year.

\section{Seasonal circulation of the Gulf of Maine}

The change in surface salinity from year 2 to year 3 is small in Fig. 6, suggesting the model has reached an equilibrium state. The year 3 model results are thus analyzed to illustrate the simulated seasonal circulation in the Gulf of Maine. We present here first the atmospherically driven, seasonal component of the circulation in the Gulf of Maine. Figures 7 and 8 show monthly averaged velocities at 10 and $100 \mathrm{~m}$ in two-month increments from the first experiment with only the atmospheric forcing. Although there is the influence from open boundaries, it does not appear to be of leading 
importance to the seasonal evolution of the circulation in the interior Gulf of Maine (see discussion later). The open boundary conditions seem to have more influence in the slope region; hence the description in this section focuses on the interior circulation, and both figures are limited to inside of the $1000-\mathrm{m}$ isobath.

The atmospheric forcing drives a distinct seasonal circulation in the interior Gulf of Maine. April marks the spinup of a cyclonic circulation, principally in the eastern gulf. During this time of the year, the Scotian Shelf water enters the Gulf of Maine, and the Maine coastal current begins to form. Circulation in the western gulf is still weak. By June, the gulf-scale cyclonic circulation pattern is established. The circulation accelerates throughout the summer and fall and reaches its maximum strength in December. During summer the northern half of the cyclonic circulation is rather near the Maine coast, whereas in late fall it moves farther offshore toward the interior basin. The fall-to-winter transition is characterized by decelerating circulation and shrinking in size. Eventually, the coastal current stops and flows are weak and less coherent in February.

Flows at 100-m depth (Fig. 8) generally follow the surface pattern. Topographic influences appear to be stronger at this level such that the basin-scale circulation tends to follow closely the $200-\mathrm{m}$ isobath and traces three deep basins. In the eastern gulf, especially in spring (April and June), there appear to be two separated cyclonic gyres around the Jordan and Georges Basin. Currents at this level tend to be much weaker during the season of strong stratification, but reach maximum intensity in December. As the surface circulation weakens in February, so do the currents at the 100-m level, and vertical velocity shears are smaller during winter. Such a time variation of the deep currents reveals a probable mechanism for a quick spindown of the circulation from December to February: when winter cooling erodes stratification, currents penetrate to deep levels, then the bottom friction leads to the spindown of the circulation.

As seen in Fig. 5, April is the month when the seasonal transition of the atmospheric forcing (from northwesterlies and cooling in winter to southwesterlies and warming in summer) occurs. To demonstrate the effects of wind and heat flux during the transition period, the last six months of the first experiment were reintegrated under the following two scenarios: 1) forced with the climatological heat flux but the steady January wind and 2 ) forced with the climatological monthly wind but zero heat flux. Results of these two 6-month runs are shown in Fig. 9a and 9b, respectively. In comparison with Fig. 7 , wind transition appears to have little effect on the circulation, whereas the circulation is considerably weaker, especially in the eastern gulf when the heat flux is set to zero. These results suggest that the heat flux plays an important role in the annual variation of the circulation. Differential heating in April (warming nearshore and cooling offshore) results in lighter waters near

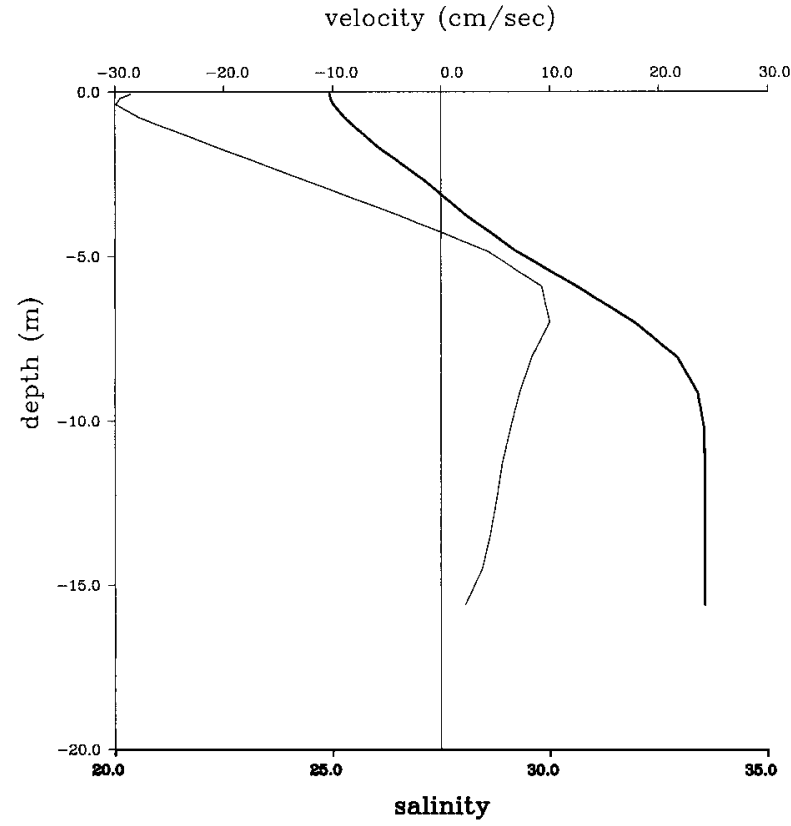

FIG. 10. Velocity (thin curve, in $\mathrm{cm} \mathrm{s}^{-1}$ ) and salinity (heavy curve) profiles at the mouth of the Saint John estuary.

shore and thus an inward pressure gradient force at depth that helps to push the water into the gulf (as seen in Northeast Channel during April in Fig. 8), which in turn may spin up the cyclonic circulation.

\section{Effects of river discharge on the seasonal circulation}

Salinity in the first experiment is much too high (Fig. 6) due to the lack of freshwater input from rivers. The combined discharge of the four largest rivers (Saint John, Penobscot, Kennebec, and Merrimack) amounts to about $8 \times 10^{11} \mathrm{~m}^{3}$ freshwater per year, which has profound influence on water properties and dynamics in estuaries and the nearby coastal water. However, the model has a resolution about $3 \mathrm{~km} \times 4 \mathrm{~km}$ near shore that is not aimed at resolving dynamic processes in estuaries. Thus special treatment is needed to parameterize physical variables near the river mouth. Single-cellwidth channels were added to the model (see Fig. 3) to approximate estuarine processes. An outflow was specified at the head of the estuary (*s in Fig. 3) with the transport equal to the climatological monthly discharge rates determined from the archived data at U.S. Geological Survey and Water Survey of Canada, and the discharged water was assumed to have zero salinity. A two-layer estuarine system developed after a few days. A velocity and a salinity profile at the mouth of the Saint John River (+ in Fig. 3) are depicted in Fig. 10. The less saline water flows out to sea on the top, and the denser water flows up estuary on the bottom. Furthermore, the model calculated salinity profile at the mouth of the estuary varies with the seasonal river dis- 


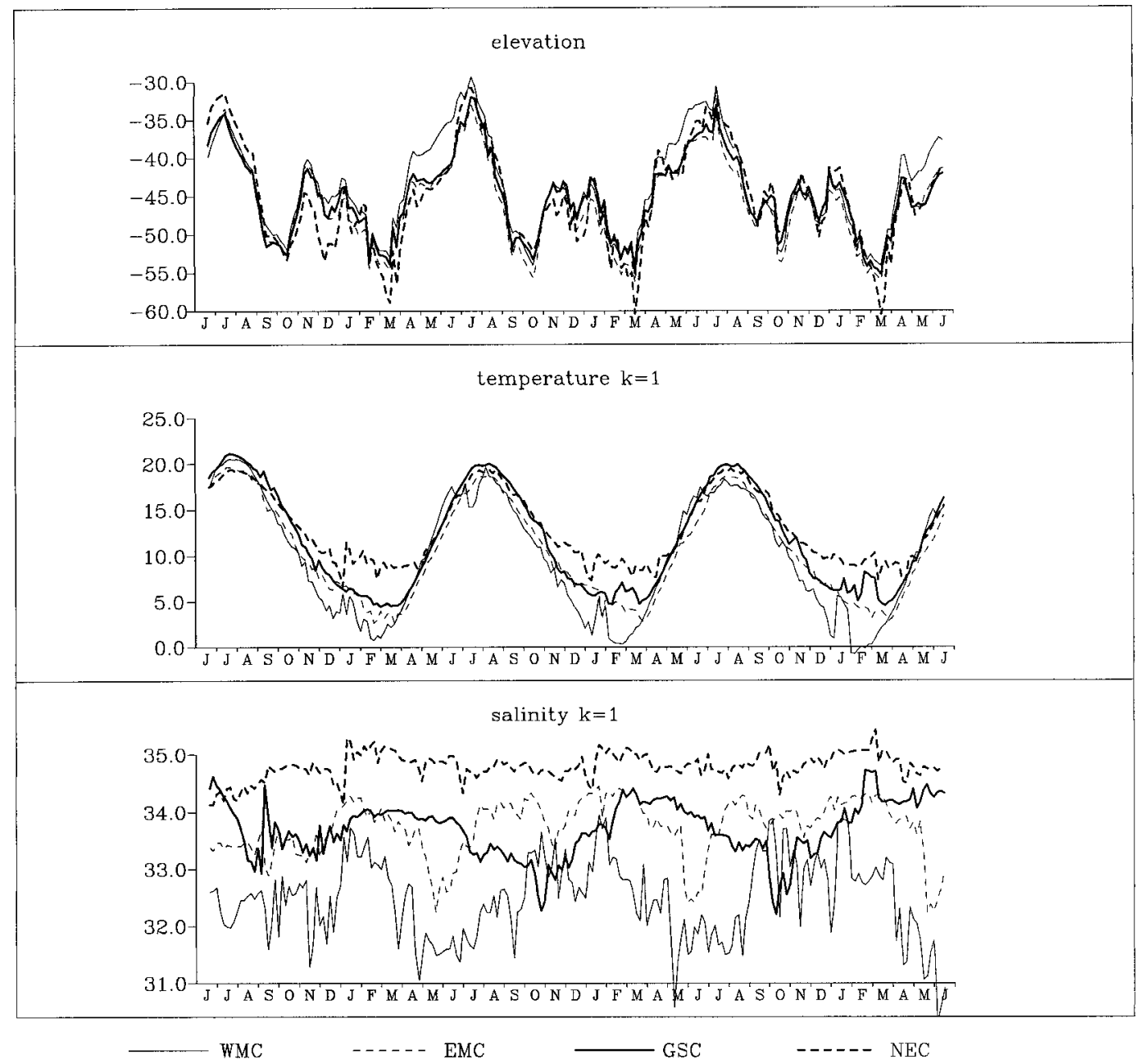

FIG. 11. As in Fig. 6 but for the experiment forced with the atmospheric forcing and river discharge.

charge, with the surface salinity being about 21 psu during high discharge season (April) to about $30 \mathrm{psu}$ during the low discharge season (September).

This second experiment (including river discharge) was also integrated for three years. Inclusion of river discharge appears to enhance the annual cycle (Fig. 11). The rise in sea surface in summer tends to be higher. This increase is particularly evident at the WMC site, which is the highest among four locations between April and July, suggesting the effect arising from a buildup of the less saline water in the western gulf. The surface temperature is lower in winter at two coastal sites because the limited discharge in winter helps to maintain the stratification near the coast. Thus cooling is limited to the top of the water column, but it tends to cool the top even more. The result is a surface temperature minimum that lasts from January to April.

The annual cycle becomes clear in surface salinity with the inclusion of river inflow. Among these four locations, the WMC site has the lowest salinity because of the accumulated effect of the Saint John, Penobscot, and especially the nearby Kennebec Rivers. Salinity begins to fall sharply in March, associated with the beginning of the spring freshet, and reaches the minimum of 31 psu in June. Since EMC is at the tailing portion of the Saint John plume, the salinity is not as low as at the WMC site. The sharp decrease at this location begins in late May, and the salinity has a minimum of $32.5 \mathrm{psu}$ in late June. The annual salinity cycle is also notable in the GSC. The spring freshet of the Merrimack River reaches the GSC site in June, and the surface salinity decreases by 1 unit (the Merrimack River has relatively small discharge rates). Surface salinity at the GSC site reaches its minimum of $32.5 \mathrm{psu}$ in October, which is likely the remnant signal of the spring freshet along the Maine coast being carried over by the cyclonic gulfscale circulation. Surface salinity at the NEC site is the highest, and its annual variation is small.

To demonstrate the effects of river discharge on the seasonal circulation in the Gulf of Maine, again the year 3 monthly averaged velocities at 10 and $100 \mathrm{~m}$ are shown respectively in Figs. 12 and 13 in two-month 

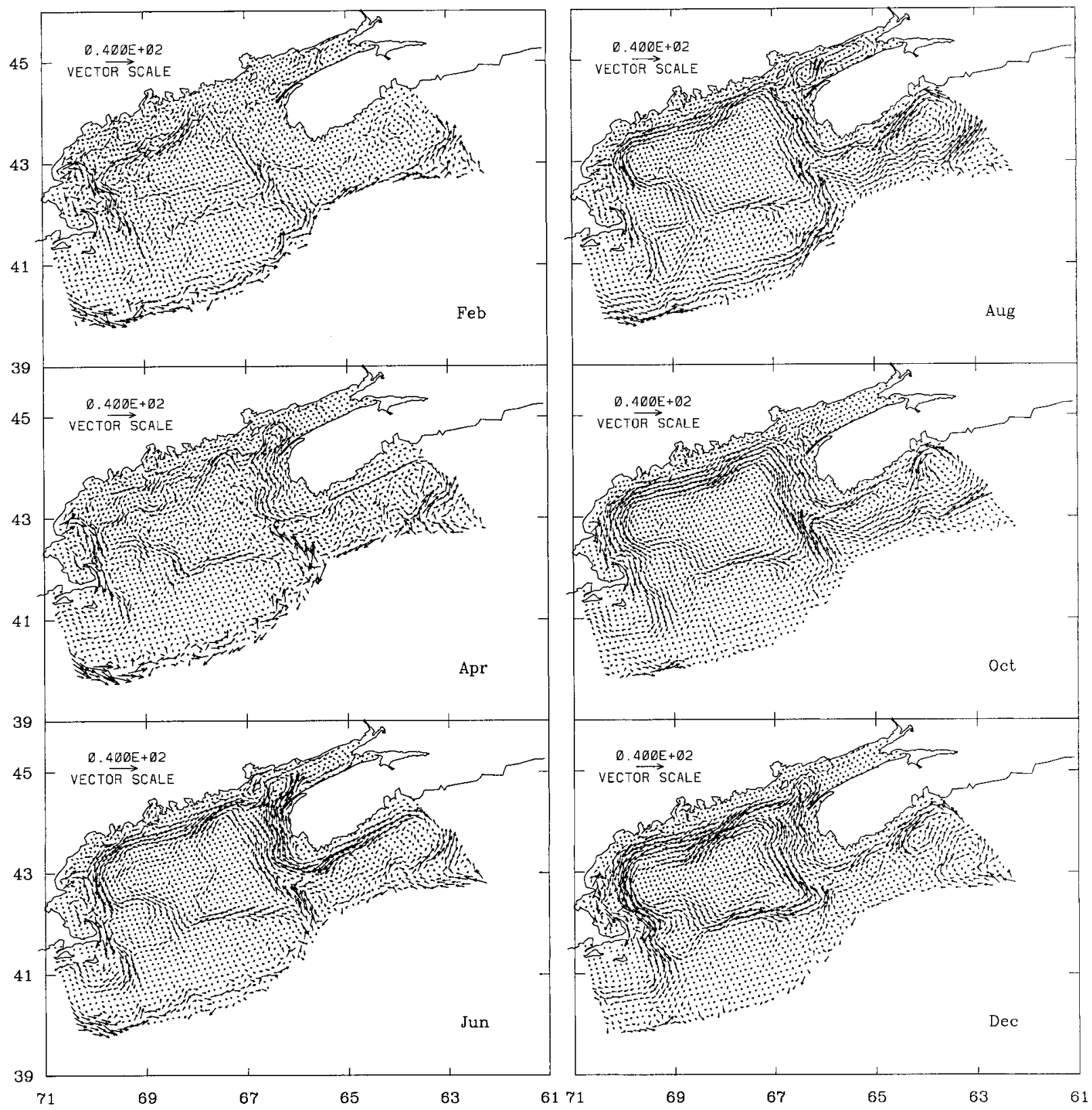

FIG. 12. As in Fig. 7 but for the experiment forced with the atmospheric forcing and river discharge.

increments. In comparison with Fig. 7, the seasonal evolution of the circulation is largely unaffected be the river discharge although the detailed pattern is somewhat different, especially in the western gulf. The coastal current is stronger in April and June due to high discharge rates during the spring freshet season. During other months the inclusion of river inflow seems to slightly weaken the cyclonic circulation. In April, the path of the coastal current along the Maine coast is distorted by the eddies associated with river discharges. In general, it tends to be farther offshore, and the current separates outside of Penobscot Bay. In June, the coastal current moves back near the shore, and the summer circulation pattern has been fully established. In the western gulf, the cyclonic circulation is farther away from the coast and appears to have a separation point east of Massachusetts Bay. Neither the pattern nor the strength of the circulation change much throughout the summer and early fall. The circulation again reaches its maximum intensity in December (the December pattern is most alike between these two experiments), and it again shrinks and spins down between December and February. Flows at the 100-m depth (Fig. 13) are weaker compared to the previous experiment as seen in Fig. 8 because the dis- 

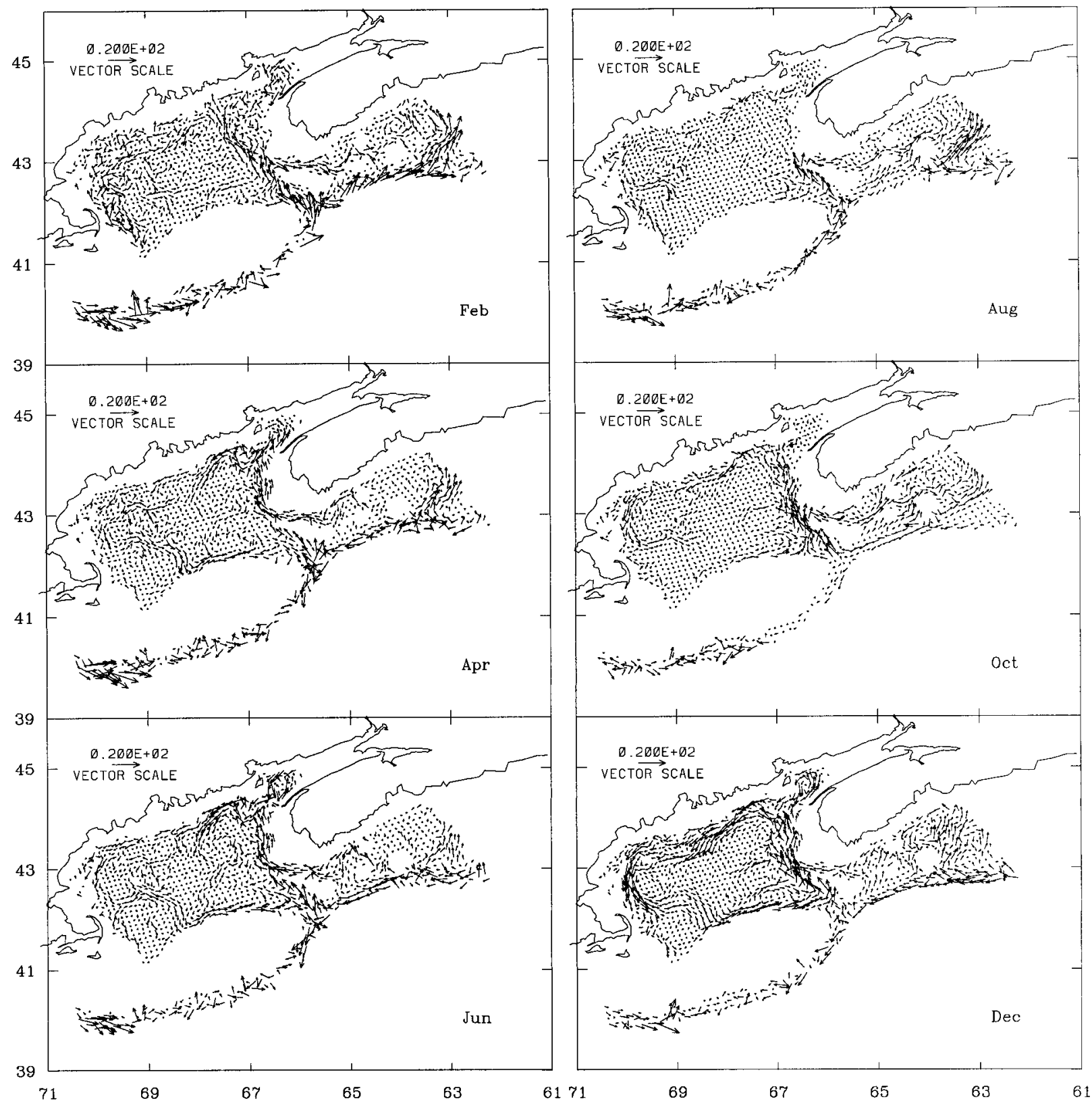

Fig. 13. Monthly averaged velocity at 100-m depth. Similar to Fig. 8 but for the experiment forced with the atmospheric forcing and river discharge.

charged freshwater increases the stratification, and in turn the circulation becomes more baroclinic. However, the overall pattern and its annual variation are quite similar with the strongest flows occurring in December, leading the spin down of the circulation.

\section{Effects of the $M_{2}$ tide on the seasonal circulation}

Although the first and the second experiment successfully simulated the cyclonic circulation in the in- terior Gulf of Maine, the anticyclonic circulation on Georges Bank was absent, most likely due to the exclusion of tides in these two experiments since tidal rectification can be strong over the Bank (e.g., Loder 1980).

The semidiurnal lunar tide $\left(M_{2}\right)$ is the predominant tidal constituent in the Gulf of Maine and Bay of Fundy system (Moody et al. 1984). It is thus added to the third experiment to demonstrate tidal effects on the seasonal circulation in the Gulf of Maine. Following Greenberg (1979), tidal forcing can be specified on the model open 


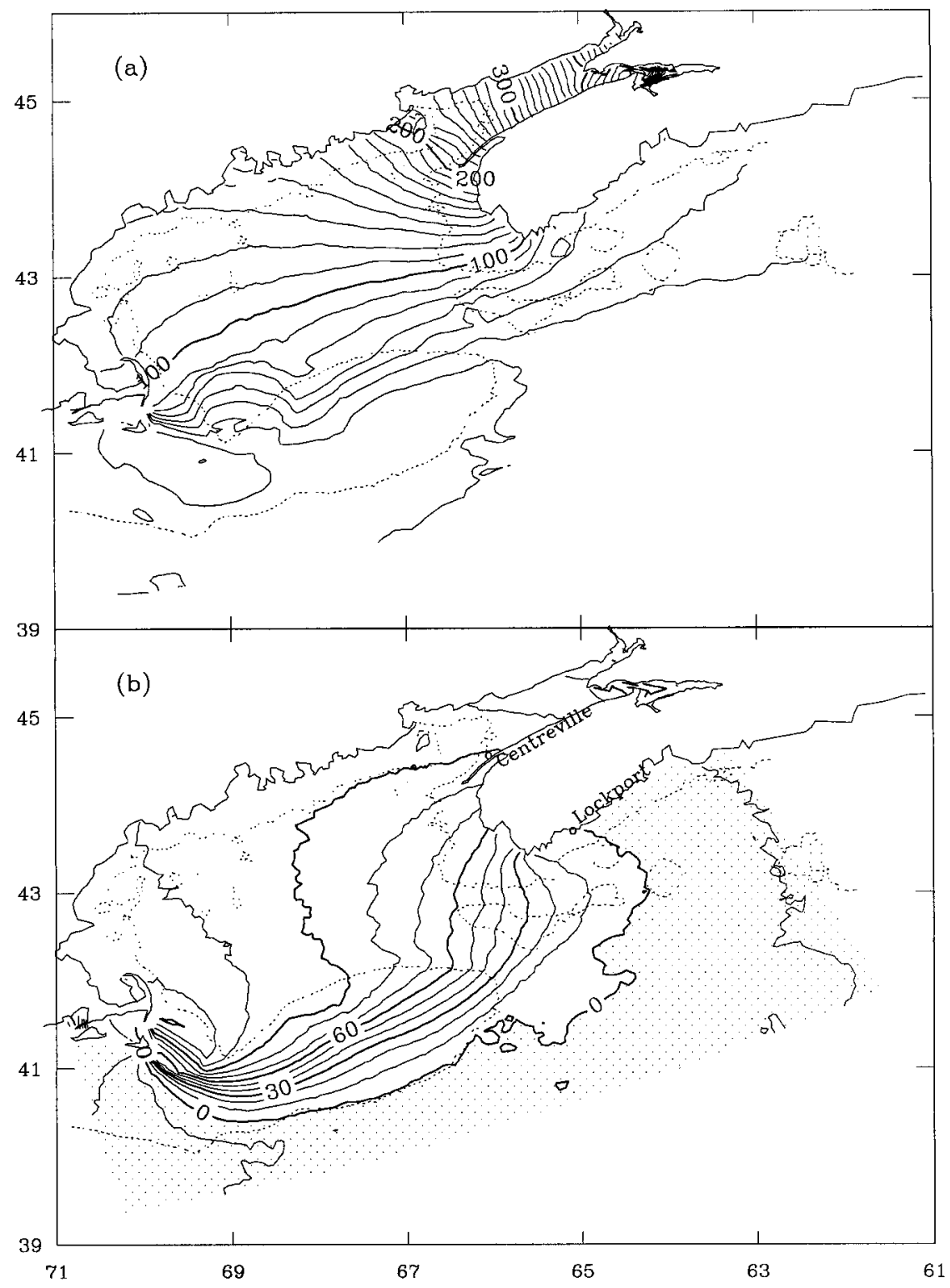

FIG. 14. Coamplitude (a) and cophase (b) chart of the modeled $M_{2}$ tide. Contour intervals are $10 \mathrm{~cm}$ for amplitude and $10^{\circ}$ for phase. Dotted curve is the $100-\mathrm{m}$ isobath.

boundary as simple sinusoidal functions with prescribed frequency, amplitude, and phase. The frequency of $M_{2}$ tide is $1.4052 \times 10^{-4} \mathrm{~s}^{-1}$ (equivalent to a period of $12.421 \mathrm{~h}$ ). Amplitudes and phases are obtained using optimal interpolation of the tidal atlas of Moody et al. (1984) and the global tidal charts of Schwiderski (1979) in the slope region because most of the stations listed in the tidal atlas of Moody et al. (1984) are inside of the shelfbreak (far away from the model open boundary) except for a few open ocean stations. The elevation of the $M_{2}$ tide, expressed as a cosine function of the frequency, amplitude, and phase, is then linearly super- imposed on the ECFS predicted monthly sea surface elevation along the model open boundary.

Figures $14 \mathrm{a}$ and $14 \mathrm{~b}$ show the coamplitude and cophase chart of the modeled $M_{2}$ tide. Amplitude is about $40 \mathrm{~cm}$ near the model open boundary, increasing slightly from west to east. There is a minimum in amplitude over Nantucket Shoals $(<30 \mathrm{~cm})$ and over Georges Bank $(<40 \mathrm{~cm})$. The amplitude, beginning from the northern flank of Georges Bank, increases northward toward the Maine coast and northeastward in the Bay of Fundy. The $0^{\circ}$ cophase line begins south of Nantucket Island, follows the 100-m isobath on the southern flank 
TABLE 1. The $M_{2}$ amplitude (AMP) in centimeters and phase (PHS) in degrees from the atlas of Moody et al. (1984) and as calculated by the model. The last two columns are their differences $(D)$.

\begin{tabular}{|c|c|c|c|c|c|c|}
\hline Stations & AMP(atlas) & PHS(atlas) & AMP(model) & PHS(model) & DAMP & DPHS \\
\hline B1 & 48.3 & 351 & 47.18 & 354 & 1.12 & -3 \\
\hline Halifax & 63 & 349 & 62.68 & 350 & 0.32 & -1 \\
\hline IAPSO.23 & 49.2 & 350 & 49.25 & 359 & -0.05 & -9 \\
\hline $\mathrm{T} 21$ & 48.9 & 357 & 48.25 & 359 & 0.65 & -2 \\
\hline Lockport & 69.8 & 359 & 73.88 & 2 & -4.08 & -3 \\
\hline $\mathrm{T} 22 \mathrm{~A}$ & 45.7 & 4 & 43.35 & 8 & 2.35 & -4 \\
\hline Т22B & 44.1 & 9 & 42.61 & 11 & 1.49 & -2 \\
\hline T3 & 39.1 & 2 & 37.56 & 3 & 1.54 & -1 \\
\hline E & 45.3 & 24 & 47.49 & 27 & -2.19 & -3 \\
\hline Seal Island & 120.4 & 52 & 126.49 & 51 & -6.09 & 1 \\
\hline Pinkney & 155.4 & 59 & 153.46 & 60 & 1.94 & -1 \\
\hline Yarmouth & 163.2 & 63 & 164.42 & 64 & -1.22 & -1 \\
\hline Part Mait. & 185.1 & 66 & 182.1 & 69 & 3 & -3 \\
\hline B6 & 88.2 & 87 & 85.72 & 85 & 2.48 & 2 \\
\hline Bar harbor & 154.9 & 93 & 151.7 & 92 & 3.2 & 1 \\
\hline Cashes Ledge & 120 & 98 & 118.6 & 96 & 1.4 & 2 \\
\hline Rockland & 150 & 98 & 143.9 & 96 & 6.1 & 2 \\
\hline Monhegan & 130.3 & 99 & 127.69 & 96 & 2.61 & 3 \\
\hline Cape Cod Light & 116 & 113 & 107.42 & 109 & 8.58 & 4 \\
\hline Portland & 133 & 103 & 130.71 & 100 & 2.29 & 3 \\
\hline Cape Porpoise & 127.2 & 103 & 125 & 101 & 2.2 & 2 \\
\hline Cape Cod Canal & 124.4 & 109 & 134.03 & 108 & -9.63 & 1 \\
\hline Portsmouth & 130.3 & 107 & 125.13 & 102 & 5.17 & 5 \\
\hline Boston & 134.5 & 111 & 128.91 & 106 & 5.59 & 5 \\
\hline Isle Haute* & 418.8 & 98 & 391.55 & 106 & 27.25 & -8 \\
\hline Margartvil* & 387.4 & 92 & 384.83 & 101 & 2.57 & -9 \\
\hline St. Martins* & 368.5 & 102 & 357.96 & 108 & 10.54 & -6 \\
\hline Centreville* & 260.6 & 92 & 252.78 & 89 & 7.82 & 3 \\
\hline Dipper Harbor* & 280.4 & 98 & 249.57 & 99 & 30.83 & -1 \\
\hline Eastport* & 261.3 & 99 & 231.87 & 98 & 29.43 & 1 \\
\hline M7 & 41 & 38 & 40.9 & 42 & 0.1 & -4 \\
\hline M5 & 40.5 & 356 & 38.06 & 355 & 2.44 & 1 \\
\hline M4 & 38.9 & 1 & 36.89 & 1 & 2.01 & 0 \\
\hline M3 & 39.6 & 22 & 35.25 & 31 & 4.35 & -9 \\
\hline M9 & 38.9 & 6 & 36.16 & 6 & 2.74 & 0 \\
\hline $\mathrm{K}$ & 39.9 & 18 & 37.24 & 23 & 2.66 & -5 \\
\hline M2 & 77.2 & 92 & 76.24 & 90 & 0.96 & 2 \\
\hline M1 & 78.2 & 92 & 79.25 & 92 & -1.05 & 0 \\
\hline LCL & 39.4 & 354 & 36.45 & 357 & 2.95 & -3 \\
\hline LCA & 39.2 & 358 & 35.27 & 359 & 3.93 & -1 \\
\hline $\mathrm{T} 23$ & 40.4 & 356 & 35.64 & 354 & 4.96 & 2 \\
\hline B & 25.9 & 47 & 23.01 & 51 & 2.89 & -4 \\
\hline $\mathrm{R}$ & 31.4 & 3 & 27.44 & 3 & 3.96 & 0 \\
\hline KIWI & 41.4 & 349 & 38.7 & 348 & 2.7 & 1 \\
\hline $\mathrm{S}^{*}$ & 32.3 & 1 & 25.64 & 333 & 6.66 & 28 \\
\hline NSFE1** & 38.7 & 356 & 31.02 & 346 & 7.68 & 10 \\
\hline NSFE2** & 40.4 & 354 & 33.79 & 344 & 6.61 & 10 \\
\hline NSFE4** & 42 & 353 & 37.18 & 343 & 4.82 & 10 \\
\hline NSFE $5 * *$ & 41.9 & 351 & 39.2 & 343 & 2.7 & 8 \\
\hline $\mathrm{P} * *$ & 41.6 & 352 & 35.44 & 342 & 6.16 & 10 \\
\hline
\end{tabular}

* The stations in the Bay of Fundy.

** The stations over Nantucket Shoals.

to the eastern tip of Georges Bank, then turns northeastward to end near Lockport, Nova Scotia. The $90^{\circ}$ cophase line begins east of Nantucket Island, runs on the northern flank of Georges Bank to about the center of the Bank, then turns northward cutting across the center of the Gulf of Maine. When it is about $50 \mathrm{~km}$ south of Mount Desert Island, the $90^{\circ}$ cophase line turns eastward again to end near Centreville, Nova Scotia. In general, the modeled coamplitude and cophase charts agree well with previous model studies (e.g., Greenberg 1979; Sucsy et al. 1993) and the tidal atlas of Moody et al. (1984) except in the upper Bay of Fundy where the model seems to underestimate the amplitude and over Nantucket Shoals where the modeled cophase lines tend to be too close to each other. Table 1 compares the modeled amplitude and phase with the atlas values of Moody et al. (1984) at 50 stations. Excluding the stations in the Bay of Fundy (* in Table 1) and stations 


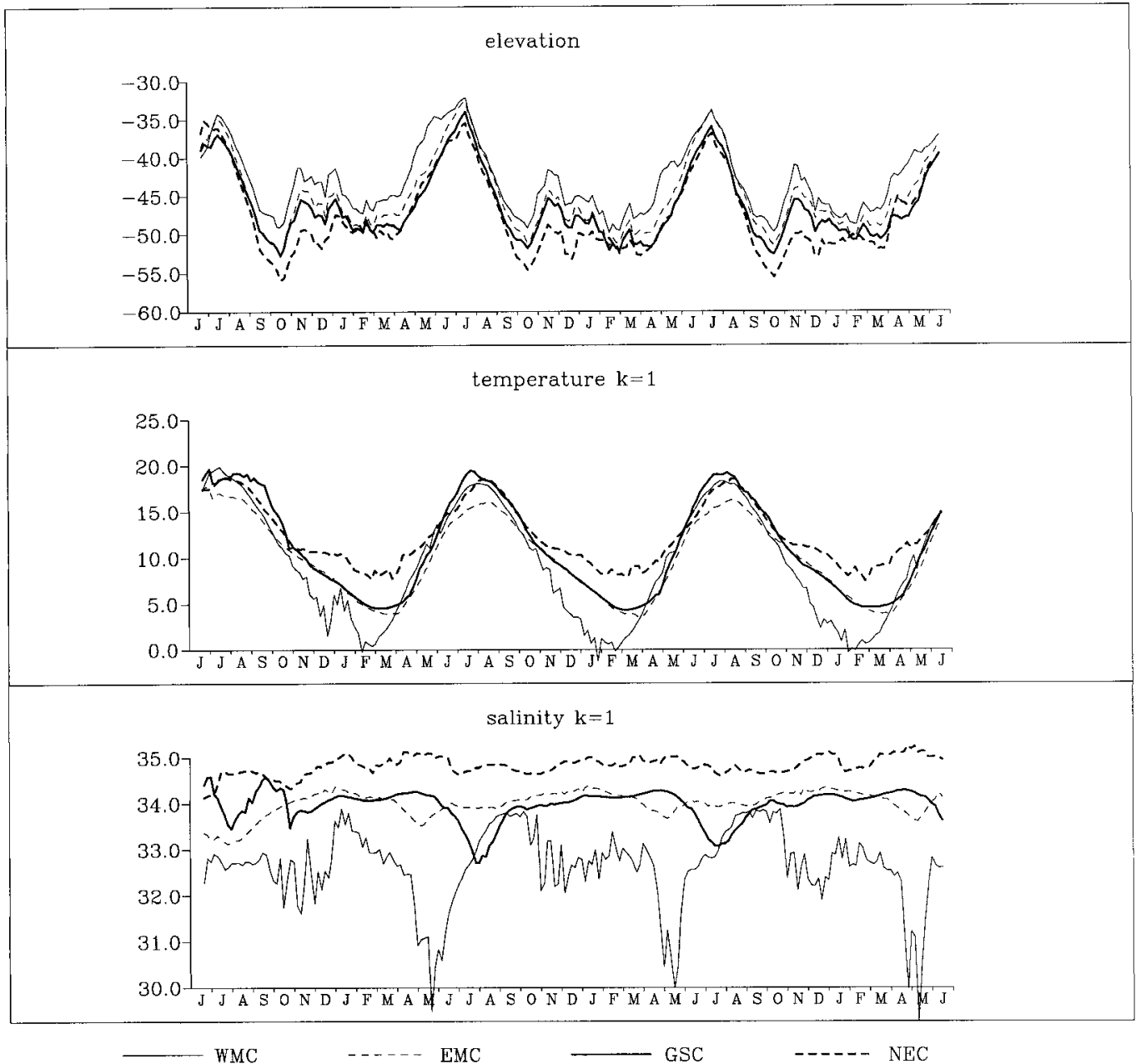

FIG. 15. As in Fig. 6 but for the experiment forced with the atmospheric forcing, river discharge, and $M_{2}$ tide.

over Nantucket Shoals $(* *$ in Table 1), rms errors of amplitude and phase for the other 38 stations are 3.65 $\mathrm{cm}$ and $3 \mathrm{deg}$.

The model is again integrated for three years with the added tidal forcing. The tide appears to affect locally water properties (Fig. 15) and the circulation (Figs. 16 and 17) through tidal mixing and tidal rectification. Among the four sites where time series were taken (Fig. 15), tidal mixing is strong at EMC where the surface temperature decreases by about $3^{\circ} \mathrm{C}$ in the summer and the minimum surface salinity in May increases by 1 unit in comparison with the case without the tidal forcing (Fig. 11). Low salinity of the coastal plume associated with the Saint John River discharge is almost undetectable off the east Maine coast due to strong tidal mixing there. The minimum surface salinity at WMC changes very little for the reason that this site is rather close to the mouth of the Kennebec estuary. However, the period of low salinity is much shorter because the discharge from the Saint John River no longer affects the salinity at WMC due to enhanced tidal mixing along the eastern Maine coast. The same is true at GSC where not only the period of low salinity is short but also the minimum surface salinity increases. In general, water level nearshore is consistently higher than that offshore, especially at WMC. Second, time series shown in Fig. 15 are smoother than those in Fig. 11, suggesting that tidal mixing suppresses mesoscale variabilities.

The third year model results are analyzed to demonstrate the modification to the seasonal circulation due to tide. Monthly averaged 10-m velocity (Fig. 16) shows a similar annual cycle with weak and incoherent currents in February. The gulfwide circulation again spins up between April and June and strengthens throughout the summer. However, the circulation appears to start weakening from October to December. The reason is that the tidal mixing reduces velocity shear in the vertical such that the velocity at lower levels becomes strong starting from August, as seen from the monthly averaged velocity at 100-m depth (Fig. 17). Therefore, the dissipation associated with bottom friction becomes effective 

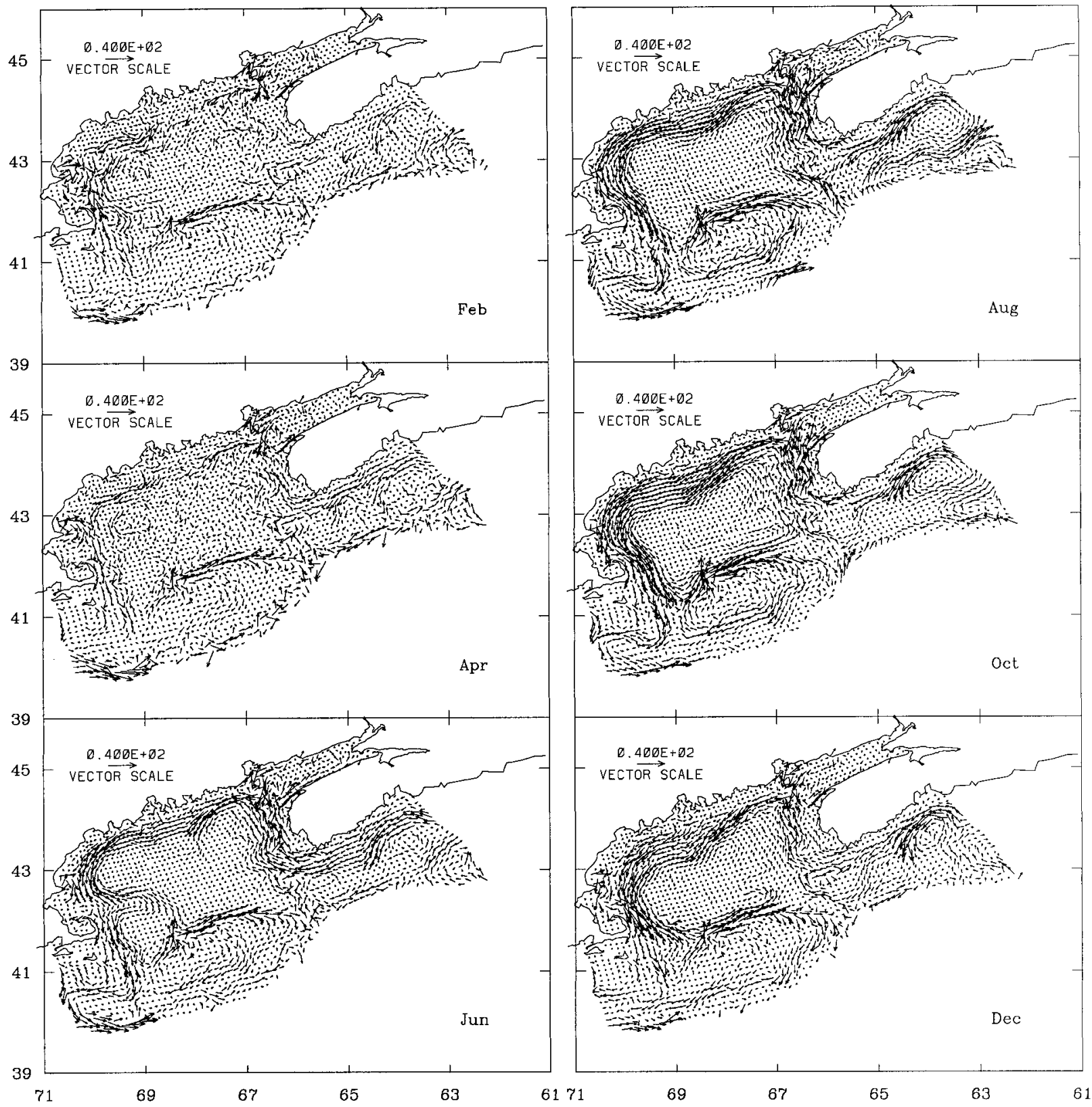

FIG. 16. As in Fig. 7 but for the experiment forced with the atmospheric forcing, river discharge, and $M_{2}$ tide.

earlier in the season. Overall, the tide appears to strengthen the summer circulation, generating a rather broad coastal current on the western side of the gulf. Most importantly, an anticyclonic circulation over Georges Bank appears as a result of tidal rectification over the bank, and this anticyclonic circulation spins up in concert with the cyclonic circulation in the interior Gulf of Maine, being strong and coherent from June to October.

Sensitivity of the modeled $M_{2}$ tide to the open boundary condition, tidal barrier in the upper Bay of Fundy, bottom boundary layer, and bottom drag coefficient has been tested. There are small, quantitative changes in amplitude and phase locally, and modification to the seasonal circulation is even smaller. Therefore, the sensitivity study is not discussed in this paper.

\section{Discussion and summary}

Detailed vernal circulation from the experiment with tide is shown in Fig. 18. Although there are rich mesoscale variabilities, the overall circulation pattern inside the shelfbreak is dominated by the cyclonic flowing coastal current system and the anticyclonic gyre on 

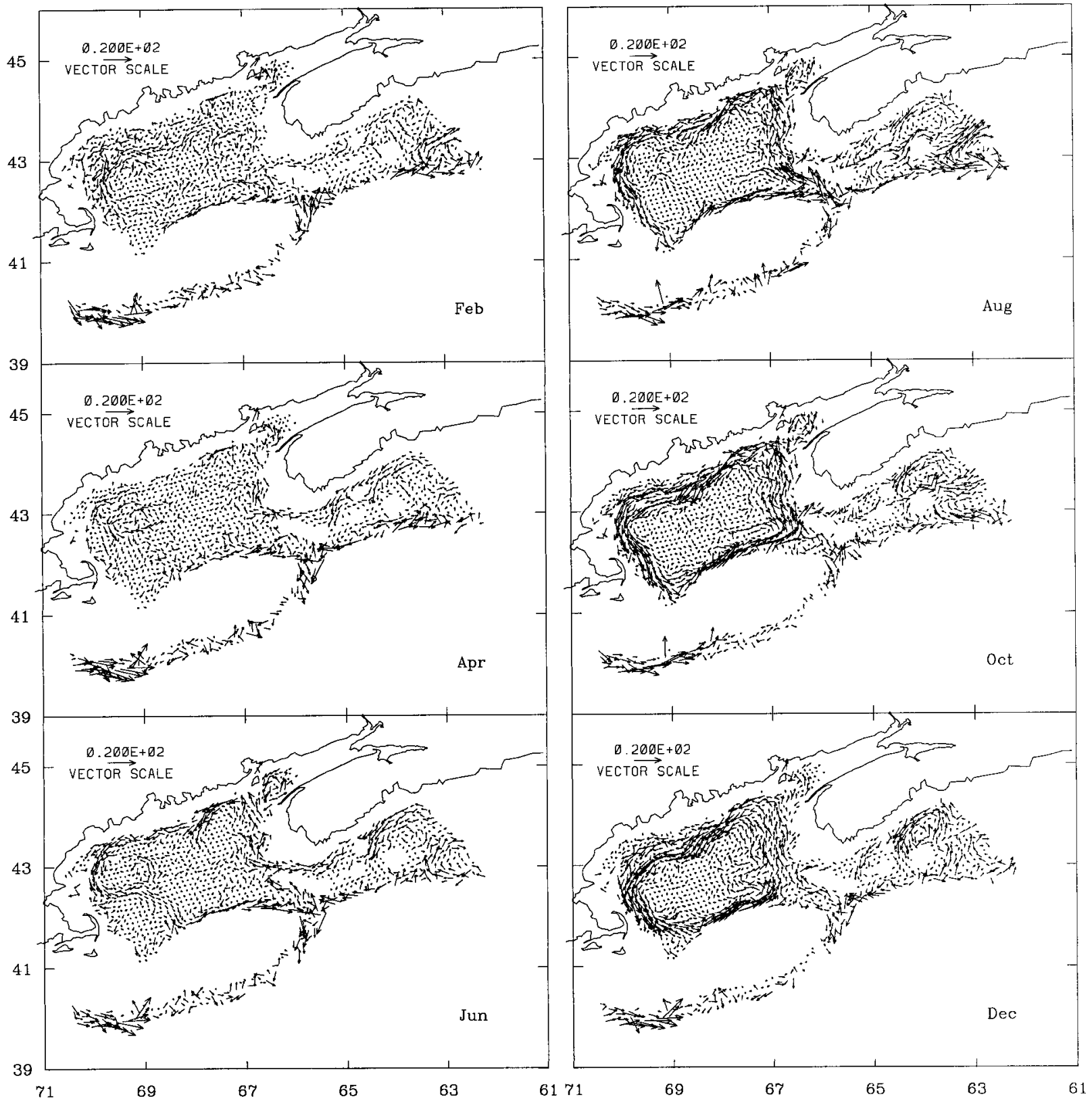

FIG. 17. As in Fig. 8 but for the experiment forced with the atmospheric forcing, river discharge, and $M_{2}$ tide.

Georges Bank. The Scotian Shelf water entering the Gulf of Maine flows northward along the west coast of Nova Scotia, then cyclonically in the Bay of Fundy. A cyclonic eddy is evident at the mouth of the Bay of Fundy. A strong coastal current exists from Grand Manan Island to the east of Mount Desert Island and veers offshore gradually. A small portion of the coastal current separates south of Mount Desert Island and flows toward the interior basin, and the rest continues to flow southwestward down the coast except for a small seaward excursion south of Penobscot Bay. The coastal current in the western gulf appears to be broad and strong, and a large seaward excursion appears east of Massachusetts Bay. The current again separates near the northern end of Great South Channel: part of it circulates anticyclonically over Georges Bank and the other part flows anticyclonically around Nantucket Shoals. There is also a strong anticyclonic eddy on Browns Bank.

Although Bigelow's (1927) schematics and the observations by Gatien (1976) both showed northeastward surface flows on the slope, modeled surface velocities on the slope (seen in Fig. 18) are too large. It appears that the open boundary condition obtained from the ECFS interferes with the outflow from the Gulf of Maine 


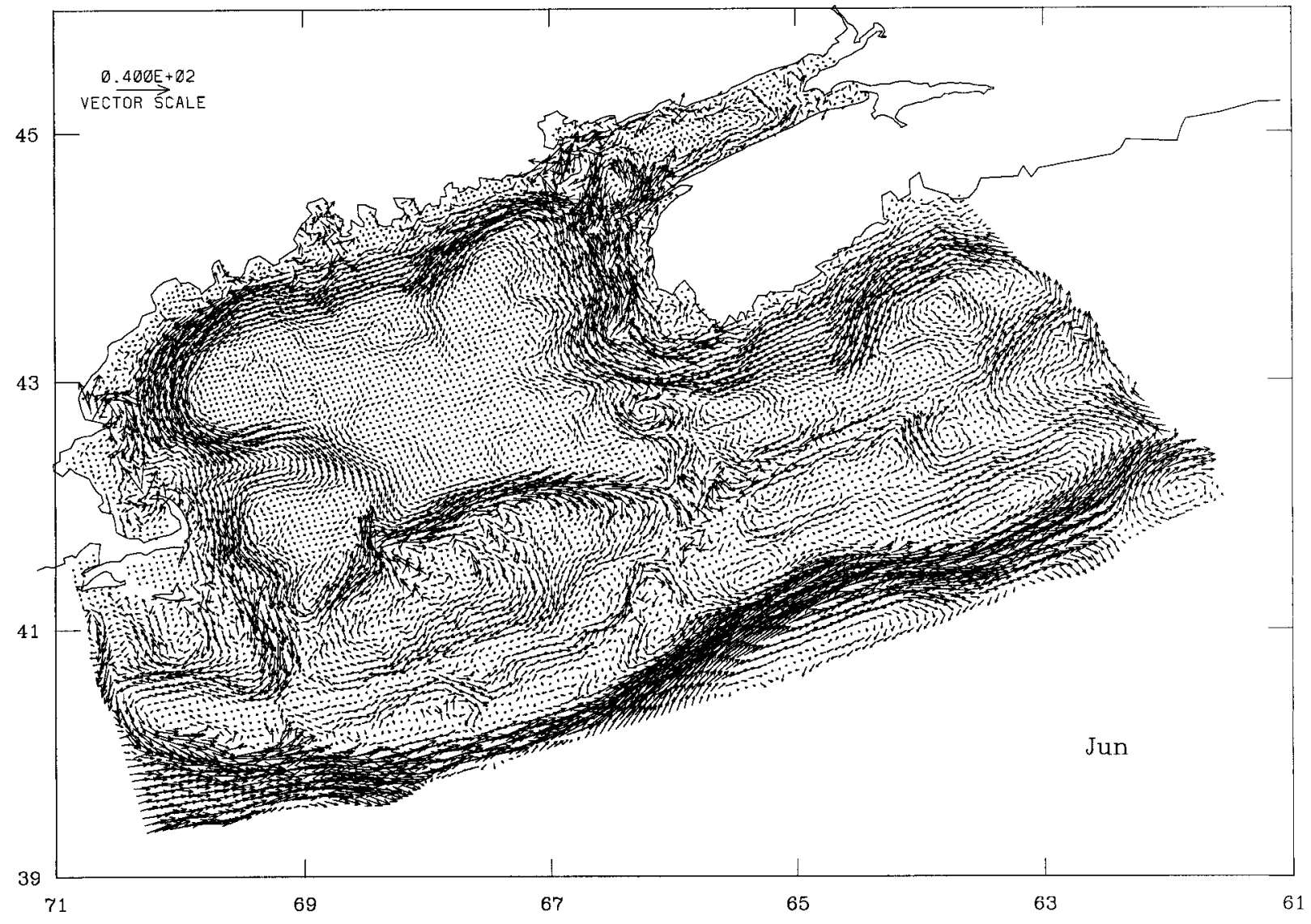

FIG. 18. June monthly averaged velocity at $10-\mathrm{m}$ depth in the experiment forced with the atmospheric forcing, river discharge, and $M_{2}$ tide. Velocity vectors are drawn at every grid point except for the boundary zone (the shaded area in Fig. 3).

and causes it to turn offshore and artificially strengthens the northeastward flow on the slope. Furthermore, the modeled flow over the shelf break (south of Georges Bank) is northeastward rather than southwestward as observed. The reason is probably that ECFS considers only the dilution of salinity but not the volume discharge from rivers, resulting northeastward transport, and setdown of sea surface elevation on the southern New England shelf (Fig. 4b). Correspondingly, there is no net southwestward flows on the Scotian Shelf in the ECFS because of the exclusion of volume discharge from the St. Lawrence River. Figure 19a shows the vertically averaged velocity across the Scotian Shelf open boundary obtained from the ECFS. There is clearly very little net transport adjacent to the coast, and there appears to be a net outflow between Emerald Basin and Emerald Bank. Nevertheless, the interior of the model adjusts such that it draws water into the gulf from the Scotian Shelf as seen in Fig. 16. Figure 19b shows the vertically averaged velocity along a transect across the Scotian Shelf about $100 \mathrm{~km}$ away from the open boundary. A coastal current appears year round with the maximum in summer and fall. Given the limited net transport at the upstream boundary, the model accommodates the coastal current by generating a cyclonic eddy on the Scotian Shelf (Fig. 16). Drinkwater et al. (1979) also mentioned the existence of a cyclonic eddy on the Scotian Shelf in summer, though more evidence is needed to confirm the eddy and to understand its mechanism. Furthermore, it is worth while to point out that the vertically averaged velocities on the slope (Figs. 19a and 19b) are southwestward although the surface flows are northeastward as seen in Figs. 16 and 17. The reason is that flows below $400 \mathrm{~m}$ are southwestward.

Finally, the surface salinity prescribed at the Scotian Shelf boundary ranges from 33 near shore to 34.5 psu on the shelf (Fig. 20). These values are about 2 units higher than the observed. Consequently, salinity in the model tends to be high. In particular, the low salinity plume off the eastern Maine coast disappears in the model after adding tidal mixing. In the experiment considering the river discharge but not tide (Fig. 20a), the salinity of the eastern Maine coastal current is about $32.5 \mathrm{psu}$, comparable to the observed value of Pettigrew et al. (1998). However, salinity increases to about 33.5 psu off the eastern Maine coast when tidal forcing is added to the model (Fig. 20b). Figure 20 suggests that the Saint John River discharge is only partially respon- 


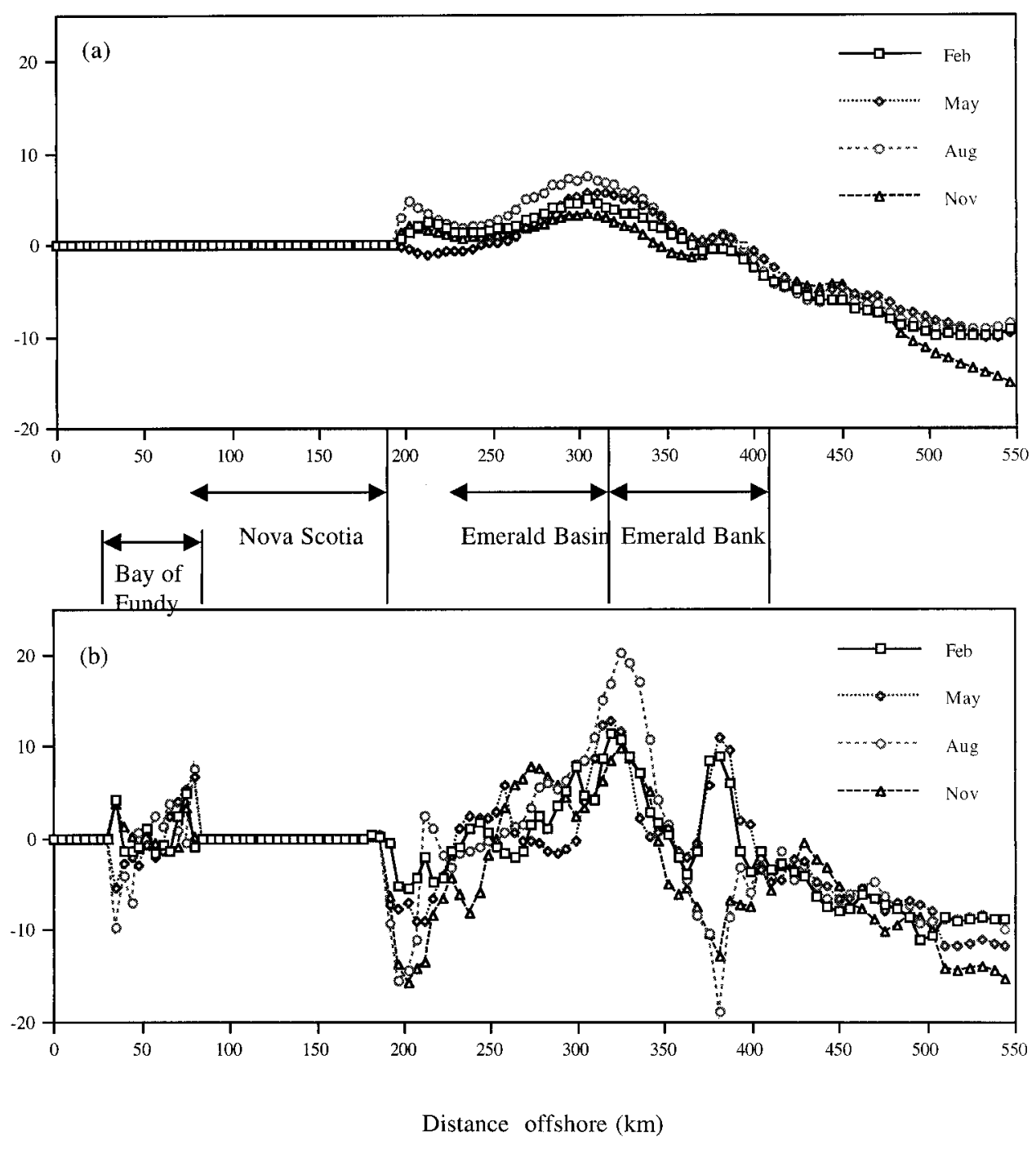

FIG. 19. Cross-shore distributions of the vertically averaged alongshore velocity $\left(\mathrm{cm} \mathrm{s}^{-1}\right)$ on the Scotian Shelf (a) at the open boundary and (b) at the transect about $100 \mathrm{~km}$ southwest of the open boundary. See Fig. 3 for the location of these two cross sections.

sible for the low salinity of the eastern Maine coastal current. The low salinity of the Scotian Shelf inflow, unfortunately missing in the current model, might be equally important. The next step is to examine the influences of the Scotian Shelf water on the thermohaline structures and the circulation in the Gulf of Maine. We have modified the transport and the properties of the Scotian Shelf inflow based on the observed monthly climatology (results will be discussed in a future paper). Although the boundary condition derived from the ECFS has the aforementioned shortcomings that could affect some of the results, it is one of the self-consistent boundary conditions that are available. Historical observations in the Gulf of Maine and neighboring regions are sufficient to compose a monthly climatology on the shelf. However, observations in deep waters are too few to form a monthly mean offshore condition. Secondly, it is hoped that the Gulf of Maine model will eventually be used in real-time simulations by coupling it with the ECFS.

The Gulf of Maine and Bay of Fundy system is extremely complicated with features of vastly differing scales and dynamics, such as river plumes, coastal currents, wind-driven flows, strong tides, thermohaline influences, and deep gyres. Its connection to the neighboring shelf and slope regions adds another degree of complexity. While it is important to be able to simulate the comprehensive picture of the circulation in the gulf, it is equally important to understand the individual components of the Gulf of Maine system. As a step in that direction, the present study uses the three-dimensional Princeton Ocean Model to examine the circulation in 


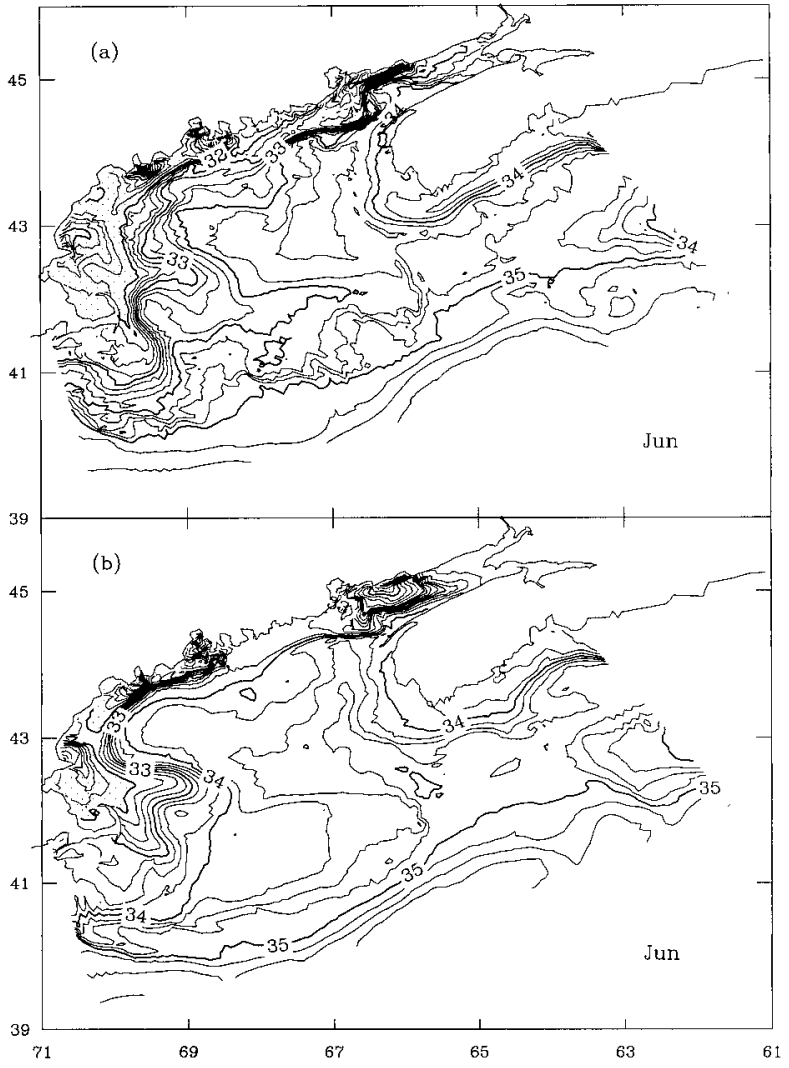

FIG. 20. June surface salinity in the experiment with river discharge (a) and in the experiment with river discharge and tidal forcing (b). Contour intervals are 0.5 for salinity less than 32 psu and 0.25 for salinity greater than 32 psu. Areas with salinity less than 32 are stippled.

the Gulf of Maine in response to atmospheric forcing, river discharge, and the $M_{2}$ tide. It is found that the atmosphere plays an important role in regulating the annual variation of the circulation. The cyclonic circulation in the gulf, which spins up first in the eastern Gulf of Maine in spring, is likely caused by differential heating between nearshore and offshore. As the season progresses, flows strengthen, the cyclonic circulation extends to the western Gulf of Maine, with the summer circulation pattern emerging by June. From June to December, the interior circulation continues to strengthen, but gradually shrinks in size. When winter cooling erodes the stratification, the cyclonic circulation penetrates deeper into the water column, most of the energy is consumed by bottom friction, and the circulation quickly spins down.

River discharge helps to establish a clear annual cycle in surface salinity. Surface salinity of the coastal current decreases by as much as 2-3 units immediately after the high discharge season. Although river discharge affects the salinity throughout the domain (though not shown, surface salinity is reduced by about 1 unit even in the interior Gulf of Maine), it does not have a marked influence on the annual cycle of the circulation. The coastal current becomes slightly stronger from April to June, and modifications of the circulation pattern appear primarily in the western gulf. A branch point appears east of Massachusetts Bay. Flows around Nantacket Shoals are anticyclonic during most of the year.

The $M_{2}$ tide contributes to the seasonal circulation in several ways: It generates an anticyclonic circulation on Georges and Browns Banks and enhances the coastal current through tidal rectification and tidal mixing. In addition, tidal mixing reduces the vertical stratification and the deep circulation becomes strong earlier in the season, resulting in earlier spindown of the circulation. Furthermore, tidal mixing tends to increase the salinity along the coast.

Acknowledgments. We thank all the researchers involved in the East Coast Forecast System for providing us the ECFS simulated monthly climatology in the Gulf of Maine region and Dave Greenberg for providing the bathymetry data. We are grateful to Dave Brooks, Rich Signell, and Dan Campbell for many insightful comments on this work. This study was supported by the NOAA Gulf of Maine Regional Marine Research Program.

\section{REFERENCES}

Aikman III, F., G. L. Mellor, T. Ezer, D. Sheinin, P. Chen, K. Bosley, and D. B. Rao, 1996: Toward and operational nowcast/forcast system for the U.S. east coast. Modern Approaches to Data Assimilation in Ocean Modeling, P. Malanotte-Rizzoli, Ed., Vol. 61, Elsevier Oceanogr. Ser., 347-376.

Bigelow, H. B., 1927: Physical oceanography of the Gulf of Maine. Fish. Bull., 40, 511-1027.

Bisagni, J. J., D. J. Gifford, and C. M. Ruhsam, 1996: The spatial and temporal distribution of the Maine Coastal Current during 1982. Contin. Shelf Res., 16, 1-24.

Blumberg, A. F., and G. L. Mellor, 1987: A description of a three dimensional coastal ocean circulation model. Three-Dimensional Coastal Ocean Models. N. Heaps, Ed., Vol. 4, Amer. Geophys. Union, 1-16.

Brooks, D. A., 1985: Vernal circulation in the Gulf of Maine. $J$. Geophys. Res., 90, 4687-4705.

- 1987: The influences of warm-core rings on slope water entering the Gulf of Maine. J. Geophys. Res., 92, 8183-8196.

- 1990: Currents at Lindenkohl Sill in the southeast GOM. $J$. Geophys. Res., 95, 22 173-22 192.

_ 1994: A model study of the buoyancy-driven circulation in the Gulf of Maine. J. Phys. Oceanogr., 24, 2387-2412.

—, and D. W. Townsend, 1989: Variability of the coastal current and nutrient pathways in the GOM. J. Mar. Res., 47, 303-321.

Brown, W. S., and J. D. Irish, 1992: The annual evolution of geostrophic flow in the Gulf of Maine. J. Phys. Oceanogr., 22, 445473.

Bumpus, D. F., 1960: Sources of water contributed to the Bay of Fundy by surface circulation. J. Fish. Res. Board Can., 17, 181197.

- and L. M. Lauzier, 1965: Surface circulation on the continental shelf of eastern North America between Newfoundland and Florida. Serial Atlas of the Marine Environment, Amer. Geogr. Soc., Folio 7, 4 pp.

Butman, B., J. W. Loderm, and R. C. Beardsley, 1987: The seasonal 
mean circulation on Georges Bank: Observations and theory. Georges Bank, R. H. Buckus, Ed., The MIT Press, 125-138.

Camerlengo, A. L., and J. J. O'Brien, 1980: Open boundary conditions in rotating fluids. J. Comput. Phys., 35, 12-35.

Chao, S.-Y., and W. C. Boicourt, 1986: Onset of estuarine plumes. J. Phys. Oceanogr., 16, 2137-2149.

Chapman, D. C., 1985: Numerical treatment of cross-shelf open boundaries in a barotropic coastal ocean model. J. Phys. Oceanogr., 15, 1060-1075.

- and R. C. Beardsley, 1989: On the origin of shelf water in the Middle Atlantic Bight. J. Phys. Oceanogr., 19, 384-391.

Chen, C., R. C. Beardsley, and R. Limeburner, 1995: A numerical study of stratified tidal rectification over finite-amplitude banks. Part II: Georges Bank. J. Phys. Oceanogr., 25, 2111-2128.

Churchill, J. H., and J. Manning, 1997: Reponse of Georges Bank waters and larvae to the passage of a Gulf Stream warm-core ring. Proc. Gulf of Maine Ecosystem Dynamics Symp. and Workshop, St. Andrews, NB, Canada, RARGOM Rep. 97-1, 287.

Day, C. G., 1958: Surface circulation in the Gulf of Maine as deduced from drift bottles. Fish. Bull., 141, 443-471.

Drinkwater, K., B. Petrie, and W. H. Sutcliffe Jr., 1979: Seasonal geostrophic volume transports along the Scotian Shelf. Estuar. Coastal Mar. Sci., 2, 17-27.

Garrett, C., 1972: Tidal resonance in the Bay of Fundy and Gulf of Maine. Nature, 238, 441-443.

Gatien, M. G., 1976: A study in the slope water region south of Halifax. J. Fish. Res. Board Can., 33, 2213-2217.

Greenberg, D. A., 1979; A numerical model investigation of tidal phenomena in the Bay of Fundy and Gulf of Maine. Mar. Geod., 12, 161-187.

_ 1983: Modeling the mean barotropic circulation in the Bay of Fundy and Gulf of Maine. J. Phys. Oceanogr., 13, 886-904.

Isaji, T., and M. L. Spaulding, 1984: A model of the tidally induced residual circulation in the Gulf of Maine and Georges Bank. $J$. Phys. Oceanogr., 14, 1119-1126.

- - - and M. Reed, 1984: A Numerical Modeling Characterization of the Annual Three-Dimensional Circulation in the Georges Bank-Gulf of Maine Region. Appl. Sci. Assoc. Inc., 64 pp.

Loder, J. W., 1980: Topographic rectification of tidal currents on the sides of Georgs Bank. J. Phys. Oceanogr., 10, 1399-1416.

—, and D. A. Greenberg, 1986: Predicted positions of tidal fronts in the Gulf of Maine. Contin. Shelf Res., 6, 397-414.

Lynch, D. R., and C. E. Naimie, 1993: The $\mathbf{M}_{2}$ tide and its residual on the outer banks of the Gulf of Maine. J. Phys. Oceanogr., 23, 2222-2253.

— F. E. Werner, D. A. Greenberg, and J. W. Loder, 1992: Diagnostic model for baroclinic, wind-driven and tidal circulation in shallow seas. Contin. Shelf Res., 12, 37-64.

— J. T. C. Ip, C. E. Naimie, and F. E. Werner, 1996: Comprehensive coastal circulation model with application to the Gulf of Maine. Contin. Shelf Res., 16, 875-906.

— M. J. Holboke, and C. E. Naimie, 1997: The Maine coastal current: Spring climatological circulation. Contin. Shelf Res., 17, 605-634.

Martinsen, E. A., and H. Engedahl, 1987: Implementation and testing of a lateral boundary scheme as an open boundary condition in a barotropic ocean model. Coastal Eng., 11, 603-627.

Mellor, G. L., 1996: Users guide for a three-dimensional, primitive equation, numerical ocean model. Princeton University, $39 \mathrm{pp}$.

—, and T. Yamada, 1982: Development of a turbulance closure model for geophysical fluid problems. Rev. Geophys. Space Phys., 20, 851-875.

Moody, J. A., and Coauthors, 1984: Atlas of tidal elevation and current observations on the Northeast American continental shelf and slope. U.S. Geological Survey Bulletin, Vol. 1611, 122 pp.

Naimie, C. E., J. W. Loder, and D. R. Lynch, 1994: Seasonal variation of the 3D residual circulation on Georges Bank. J. Geophys. Res., 99, 15 967-15 989.

Noble, M., B. Butman, and E. William, 1983: On the longshelf structure and dynamics of subtidal currents on the eastern United States continental shelf. J. Phys. Oceanogr., 13, 2125-2147.

Oey, L.-Y., and P. Chen, 1992: A model simulation of circulation in the northeast Atlantic shelves and seas. J. Geophys. Res., 97, $20087-20115$.

— G. G. Mellor, and R. I. Hires, 1985a: A three-dimensional simulation of the Hudson-Raritan estuary. Part I: Description of the model and model simulations. J. Phys. Oceanogr., 15, 16761692.

,-- , and $-1985 \mathrm{~b}$ : A three-dimensional simulation of the Hudson-Raritan estuary. Part II: Comparison with observations. J. Phys. Oceanogr., 15, 1693-1709.

,-- and $\longrightarrow, 1985 \mathrm{c}$ : A three-dimensional simulation of the Hudson-Raritan estuary. Part III: Salt flux analyses. J. Phys. Oceanogr., 15, 1711-1720.

Orlanski, I., 1976: A simple boundary condition for bounded hyperbolic flows. J. Comput. Phys., 21, 251-269.

Pettigrew, N. R., and R. D. Hetland, 1995: The cyclonic circulation of the eastern Gulf of Maine. TOS abstract.

- $-\longrightarrow$, and J. P. Wallinga, 1997: Cyclonic circulation of the eastern Gulf of Maine. Proc. Gulf of Maine Ecosystem and Dynamics Symp. and Workshop, St. Andrews, NB, Canada, RARGOM Rep. 97-1, 307.

, D. W. Townsend, H. Xue, J. P. Wallinga, P. J. Brickley, and R. D. Hetland, 1998: Observations of the Eastern Maine Coastal Current and its offshore extensions. J. Geophys. Res., 103, $30623-30640$.

Ramp, S., R. J. Schlitz, and W. R. Wright, 1985: The deep flow through the Northeast Channel, Gulf of Maine. J. Phys. Oceanogr., 15, 1790-1808.

Schwiderski, E. W., 1979: Global ocean tides, Part II: The semidiurnal principal lunar tide $\left(\mathrm{M}_{2}\right)$. Atlas of Tidal Charts and Maps, NSWCTR 79-414.

Signell, R. P., H. L. Jenter, and A. F. Blumberg, 1994: Modeling the seasonal circulation in Massachusetts Bay. Estuarine and Coastal Modeling III: Proc 3d Int. Conf. Waterway, Port, Coastal and Ocean Div., ASCE, 578-590.

Skogen, D. M., E. Svendsen, J. Berntsen, D. Aksnes, and K. B. Ulvestad, 1995: Modeling the primary production in the North Sea using a coupled three-dimensional physical-chemical-biological ocean model. Estuar. Coastal Shelf Sci., 41, 545-565.

Smagorinsky, J., 1963: General circulation experiments with the primitive equations, I. The basic experiment. Mon. Wea. Rev., 91, 99-164.

Smith, P. C., 1983: The mean and seasonal circulation off southeast Nova Scotia. J. Phys. Oceanogr., 13, 1034-1054.

Spall, M. A., and W. R. Holland, 1991: A nested primitive equation model for oceanic applications. J. Phys. Oceanogr., 21, 205220.

Sucsy, P. V., B. R. Pearce, and V. G. Panchang, 1993: Comparison of two- and three-dimensional model simulation of the effects of a tidal barrier on the Gulf of Maine tides. J. Phys. Oceanogr., 23, 1231-1248.

Sutcliffe, W. H., Jr., R. H. Loucks, and K. F. Drinkwater, 1976: Coastal circulation and physical oceanography of the Scotian Shelf and the Gulf of Maine. J. Fish. Res. Board Can., 33, 98-115.

Tee, K.-T., P. C. Smith, and D. Lefaivre, 1993: Topographic upwelling off southeast Nova Scotia. J. Phys. Oceanogr., 23, 1703-1726.

Townsend, D. W., and N. R. Pettigrew, 1996: The role of frontal currents in larval fish transport on Georges Bank. Deep-Sea Res., 43, 1773-1792.

Vermersch, J. A., R. C. Beardsley, and W. S. Brown, 1979: Winter circulation in the Western Gulf of Maine: Part 2. Current and pressure observations. J. Phys. Oceanogr., 9, 768-784.

Woodruff, S. D., S. J. Lubker, K. Wolter, S. J. Worley, and J. D. Elms, 1993: Comprehensive Ocean-Atmosphere Data Set (COADS) Release 1a: 1980-92. Earth System Monitor, Vol. 4, No.1, 1-8. 
Wright, D. G., and J. W. Loder, 1988: On the influences of nonlinear bottom friction on the topographic rectification of tidal currents. Geophys. Astrophys. Fluid Dyn., 42, 227-245.

—, D. A. Greenberg, J. W. Loder, and P. C. Smith, 1986: The steady-state barotropic response of the Gulf of Maine and ad- jacent regions to surface wind stress. J. Phys. Oceanogr., 16, 947-966.

Zhang, D., H. Chang, N. L. Seaman, T. T. Warner, and J. M. Fritsch, 1986: A two-way interacting nesting procedure with variable terrian resolution. Mon. Wea. Rev., 114, 1330-1339. 